\title{
The Cardiac Ryanodine Receptor Provides a Suitable Pathway for the Rapid Transport of Zinc $\left(\mathrm{Zn}^{2+}\right)$
}

\author{
Jana Gaburjakova * and Marta Gaburjakova *
}

Citation: Gaburjakova, J.; Gaburjakova, M. The Cardiac Ryanodine Receptor Provides a Suitable Pathway for the Rapid Transport of Zinc $\left(\mathrm{Zn}^{2+}\right)$. Cells 2022, 11, 868. https://doi.org/10.3390/ cells11050868

Academic Editors: Jeremy M. Crook and Eva Tomaskovic-Crook

Received: 2 February 2022

Accepted: 1 March 2022

Published: 3 March 2022

Publisher's Note: MDPI stays neutral with regard to jurisdictional claims in published maps and institutional affiliations.

Copyright: (c) 2022 by the authors. Licensee MDPI, Basel, Switzerland. This article is an open access article distributed under the terms and conditions of the Creative Commons Attribution (CC BY) license (https:/ / creativecommons.org/licenses/by/ $4.0 /)$.
Centre of Biosciences, Institute of Molecular Physiology and Genetics, Slovak Academy of Sciences, Dubravska cesta 9, 84005 Bratislava, Slovakia

* Correspondence: jana.gaburjakova@savba.sk (J.G.); marta.gaburjakova@savba.sk (M.G.)

\begin{abstract}
The sarcoplasmic reticulum (SR) in cardiac muscle is suggested to act as a dynamic storage for $\mathrm{Zn}^{2+}$ release and reuptake, albeit it is primarily implicated in the $\mathrm{Ca}^{2+}$ signaling required for the cardiac cycle. A large $\mathrm{Ca}^{2+}$ release from the SR is mediated by the cardiac ryanodine receptor (RYR2), and while this has a prominent conductance for $\mathrm{Ca}^{2+}$ in vivo, it also conducts other divalent cations in vitro. Since $\mathrm{Zn}^{2+}$ and permeant $\mathrm{Mg}^{2+}$ have similar physical properties, we tested if the RYR2 channel also conducts $\mathrm{Zn}^{2+}$. Using the method of planar lipid membranes, we evidenced that the RYR2 channel is permeable to $\mathrm{Zn}^{2+}$ with a considerable conductance of $81.1 \pm 2.4 \mathrm{pS}$, which was significantly lower than the values for $\mathrm{Ca}^{2+}(127.5 \pm 1.8 \mathrm{pS})$ and $\mathrm{Mg}^{2+}(95.3 \pm 1.4 \mathrm{pS})$, obtained under the same asymmetric conditions. Despite similar physical properties, the intrinsic $\mathrm{Zn}^{2+}$ permeability $\left(\mathrm{P}_{\mathrm{Ca}} / \mathrm{P}_{\mathrm{Zn}}=2.65 \pm 0.19\right)$ was found to be $\sim 2.3$-fold lower than that of $\mathrm{Mg}^{2+}\left(\mathrm{P}_{\mathrm{Ca}} / \mathrm{P}_{\mathrm{Mg}}=1.146 \pm 0.071\right)$. Further, we assessed whether the channel itself could be a direct target of the $\mathrm{Zn}^{2+}$ current, having the $\mathrm{Zn}^{2+}$ finger extended into the cytosolic vestibular portion of the permeation pathway. We attempted to displace $\mathrm{Zn}^{2+}$ from the RYR2 $\mathrm{Zn}^{2+}$ finger to induce its structural defects, which are associated with RYR2 dysfunction. $\mathrm{Zn}^{2+}$ chelators were added to the channel cytosolic side or strongly competing cadmium cations $\left(\mathrm{Cd}^{2+}\right)$ were allowed to permeate the RYR2 channel. Only the $\mathrm{Cd}^{2+}$ current was able to cause the decay of channel activity, presumably as a result of $\mathrm{Zn}^{2+}$ to $\mathrm{Cd}^{2+}$ replacement. Our findings suggest that the RYR2 channel can provide a suitable pathway for rapid $\mathrm{Zn}^{2+}$ escape from the cardiac SR; thus, the channel may play a role in local and/or global $\mathrm{Zn}^{2+}$ signaling in cardiomyocytes.
\end{abstract}

Keywords: cardiac muscle; ryanodine receptor; zinc $\left(\mathrm{Zn}^{2+}\right)$; conductance; permeability coefficient; planar lipid membrane

\section{Introduction}

Zinc $\left(\mathrm{Zn}^{2+}\right)$ is one of the most abundant metal cations in mammalian cells, with diverse functions in numerous physiological processes important for differentiation, growth and survival (reviewed in [1,2]). Although, $\mathrm{Zn}^{2+}$ has been generally considered to have moderate biological importance, significant advances in understanding $\mathrm{Zn}^{2+}$ biology in the past decade have changed this view. Reflecting the physiological relevance, both $\mathrm{Zn}^{2+}$ deficiency and excess have been documented in a wide range of pathological conditions, including cancer, diabetes and inflammatory, cardiovascular and neurodegenerative diseases, which have been the topic of several review articles [3-9]. While catalytic and structural functions of $\mathrm{Zn}^{2+}$ are well-established in a great number of metalloproteins [10,11], $\mathrm{Zn}^{2+}$ signaling capacities have only recently received extensive attention, mainly in a cellular and molecular context.

The $\mathrm{Zn}^{2+}$ affinity to protein metal binding sites is highly competitive towards $\mathrm{Mg}^{2+}$ and $\mathrm{Ca}^{2+}$, therefore, free intracellular $\mathrm{Zn}^{2+}$ concentration is tightly controlled and fluctuates in an extraordinarily narrow range (pM-nM), depending on the cell type [12-15]. In addition to cytosolic $\mathrm{Zn}^{2+}$-chelating proteins (reviewed in [16]), various $\mathrm{Zn}^{2+}$ transporters (carriertype) are involved in controlling intracellular $\mathrm{Zn}^{2+}$, such as $\mathrm{ZnT}$ proteins exporting $\mathrm{Zn}^{2+}$ from the cytoplasm and ZIP proteins with the opposite function (reviewed in [17-19]). 
ZnT and ZIP proteins have a distinct subcellular location, depending on their contribution to $\mathrm{Zn}^{2+}$ mobilization. In mammals, they are mostly localized to the plasma membrane [20-26] or in membranes of intracellular organelles, such as the ER and Golgi apparatus [27-33]. All these intracellular compartments obviously accumulate $\mathrm{Zn}^{2+}$ [34-36], but only some could be implicated in $\mathrm{Zn}^{2+}$ signaling, exemplified by $\mathrm{Zn}^{2+}$ transients and waves [35,37]. Although, there is no clear evidence, it can be proposed that the SR in cardiomyocytes acts as a dynamic storage for $\mathrm{Zn}^{2+}$ cations, readily available for release [8,38]. These results strongly imply the presence of $\mathrm{Zn}^{2+}$ transporters, and indeed ZIP and $\mathrm{ZnT}$ proteins have been evidenced in the heart tissue $[27,39,40]$. Moreover, their predominant subcellular localization in the SR membrane has been demonstrated [41].

It is well established that the release and accumulation of $\mathrm{Ca}^{2+}$ by the SR in cardiomyocytes is fundamental to the excitation-contraction coupling [42-44]. The cyclic release of $\mathrm{Ca}^{2+}$ required for contraction is mediated by the cardiac ryanodine receptor (RYR2) displaying a remarkable conductance for $\mathrm{Ca}^{2+}[45,46]$ compared to other $\mathrm{Ca}^{2+}$-permeable channels $[47,48]$. However, the RYR2 channel discriminates only slightly between divalent cations [46], and thus has been shown to be also permeable to $\mathrm{Mg}^{2+}, \mathrm{Sr}^{2+}$ and $\mathrm{Ba}^{2+}[46,49-51]$. Since we noticed that both $\mathrm{Mg}^{2+}$ and $\mathrm{Zn}^{2+}$ possess similar physical properties relevant to permeation through ion channels [52-54], we examined whether the RYR2 channel provides a suitable permeation pathway for $\mathrm{Zn}^{2+}$. At the single-channel level, we established that $\mathrm{Zn}^{2+}$ greatly permeated the RYR2 channel in the lumen-to-cytosol direction, although with a lower conductance and intrinsic permeability than $\mathrm{Ca}^{2+}$ and even $\mathrm{Mg}^{2+}$. Our results indicate that the RYR2 channel may play a role in $\mathrm{Zn}^{2+}$ signaling in cardiomyocytes, and the channel itself could be a direct target for the localized $\mathrm{Zn}^{2+}$ increase, with the $\mathrm{Zn}^{2+}$ finger, a well-known $\mathrm{Zn}^{2+}$-binding site, extending into the cytosolic vestibular portion of the RYR2 permeation pathway [55].

\section{Materials and Methods}

\subsection{Single-Channel Recordings}

The sarcoplasmic reticulum (SR) microsomes enriched in RYR2 channels isolated from rat ventricular muscle were used for single-channel recordings as described previously [51] with some modifications. Planar lipid membranes (BLMs) were formed across a 50-70 $\mu \mathrm{m}$ aperture in the wall of a polystyrene cup separating two compartments, cytosolic and luminal.

The cytosolic compartment was filled with $1 \mathrm{~mL}$ of $50 \mathrm{mM} \mathrm{KCl}, 10 \mathrm{mM}$ Tris and $20 \mathrm{mM}$ HEPES $(\mathrm{pH}=7.35)$. The free cytosolic $\mathrm{Ca}^{2+}$ concentration of $90 \mathrm{nM}$ was obtained by including $1 \mathrm{mM}$ ethylene glycol-bis( $\beta$-aminoethylether)- $N, N, N^{\prime}, N^{\prime}$-tetraacetic acid (EGTA) and $0.587 \mathrm{mM} \mathrm{CaCl}_{2}$. In some cases, $N, N, N^{\prime}, N^{\prime}$-tetrakis(2-pyridylmethyl)-ethylene diamine (TPEN) or nitrilotriacetic acid (NTA) was used to chelate $\mathrm{Zn}^{2+}$ impurities in the cytosolic solutions. The free $\mathrm{Zn}^{2+}\left(\left[\mathrm{Zn}^{2+}\right]_{C}\right)$ and $\mathrm{Ca}^{2+}\left(\left[\mathrm{Ca}^{2+}\right]_{C}\right)$ concentrations were determined by WinMaxc32 version 2.50 (http:/ / www.stanford.edu/ cpatton/maxc.html, accessed on 24 April 2021). In control experiments, the luminal compartment was filled with $1 \mathrm{~mL}$ of 1-8 $\mathrm{mM} \mathrm{Ca}(\mathrm{OH})_{2}, 50 \mathrm{mM} \mathrm{KCl}, 10 \mathrm{mM}$ Tris and 22-43 mM HEPES ( $\left.\mathrm{pH}=7.35\right)$. In molefraction experiments for luminal $\mathrm{Mg}^{2+}$ or $\mathrm{Ca}^{2+}$, prior to formation of the BLM, 4-7 mM of $\mathrm{MgCl}_{2}$ or $\mathrm{CaCl}_{2}$ was added to the luminal solution to obtain varied mixtures with 1-4 mM $\mathrm{Ca}(\mathrm{OH})_{2}$ while maintaining the total divalent concentration at $8 \mathrm{mM}$. For pure $\mathrm{Mg}^{2+}$ or $\mathrm{Ca}^{2+}$, the luminal compartment was filled with $1 \mathrm{~mL}$ of $8 \mathrm{mM} \mathrm{MgCl}_{2}$ or $\mathrm{CaCl}_{2}, 50 \mathrm{mM} \mathrm{KCl}$, $10 \mathrm{mM}$ Tris and $20 \mathrm{mM}$ HEPES ( $\mathrm{pH}=7.35)$. The fusion of SR microsomes with the BLM was not successful enough when $\mathrm{Zn}^{2+}$ was present on the BLM luminal side, therefore, the RYR2 channel was exposed to $8 \mathrm{mM} \mathrm{ZnCl}_{2}, 50 \mathrm{mM} \mathrm{KCl}, 10 \mathrm{mM}$ Tris and $20 \mathrm{mM}$ HEPES $(\mathrm{pH}=6.83)$ by perfusing the luminal compartment after channel reconstitution under control conditions. In mole-fraction experiments, $4-7 \mathrm{mM} \mathrm{ZnCl}_{2}$ was also added to 1-4 mM $\mathrm{Ca}(\mathrm{OH})_{2}$ after RYR2 reconstitution. In addition, mixtures of $8 \mathrm{mM} \mathrm{Ca}(\mathrm{OH})_{2}$ with $8 \mathrm{mM}$ $\mathrm{ZnCl}_{2}$ or $8 \mathrm{mM} \mathrm{CdCl}_{2}$ were also tested. In the control and for the $\mathrm{MCl}_{2}$ additions (4-7 $\mathrm{mM}$ ), 1-2 mM cytosolic caffeine was used to moderately activate RYR2 channels (M: Mg, Zn or Ca). Similarly, these caffeine concentrations were sufficient for the activation of channels 
exposed to $8 \mathrm{mM} \mathrm{Ca}(\mathrm{OH})_{2}$ mixed with $8 \mathrm{mM} \mathrm{ZnCl}_{2}$ or $8 \mathrm{mM} \mathrm{CdCl}_{2}$. When $\mathrm{ZnCl}_{2}$ or $\mathrm{MgCl}_{2}$ was present in the luminal solution alone, caffeine concentration was increased to $6-7 \mathrm{mM}$ to achieve a moderate RYR2 activity. The channel was incorporated into the BLM in a fixed orientation with the cytosolic side always exposed to the cytosolic solution because all RYR2 channels were sensitive to cytosolic caffeine [55-58]. At the end of experiments, the addition of ryanodine causing the characteristic transition to a half-conducting state was used to validate the channel identity [59].

\subsection{Acquisition and Analysis of Single-Channel Recordings}

Data acquisition and analysis of the open probability $\left(\mathrm{P}_{\mathrm{O}}\right)$, frequency of opening $(F)$, average open $\left(T_{O}\right)$ and closed times $\left(T_{C}\right)$ were performed as detailed in $[51,60]$. The conductance $(\mathrm{G})$ and the reversal potential $\left(\mathrm{E}_{\mathrm{rev}}\right)$ were determined from a linear regression of the current-voltage relationship, acquired by applying membrane voltage varying from $-20 \mathrm{mV}$ to $+20 \mathrm{mV}$. The slope of the fitted line was equal to $\mathrm{G}$, and $E_{\text {rev }}$ was taken as the intersection of the voltage axis with the linear fit. To avoid misinterpretation of $E_{\text {rev }}$ measurements, the $E_{\text {rev }}$ value was further corrected for the measured offset voltage at the end of the experiment and liquid junction potentials (LJPs). The LJP values were determined for all tested luminal solutions according to Barry et al. [61] and were in the range from $-0.18 \mathrm{mV}$ to $+0.76 \mathrm{mV}$. The current amplitude at $0 \mathrm{mV}\left(\mathrm{I}_{0}\right)$ was consequently corrected. For tested $\mathrm{M}^{2+}\left(\mathrm{M}^{2+}: \mathrm{Mg}^{2+}, \mathrm{Zn}^{2+}\right.$ or $\left.\mathrm{Ca}^{2+}\right)$, the dependence of $\mathrm{E}_{\text {rev }}$ on a composition of $\mathrm{M}^{2+} / \mathrm{Ca}^{2+}$ mixture on the RYR2 luminal face was fitted by the following equation to determine the relative $\mathrm{Ca}^{2+} / \mathrm{M}^{2+}$ permeability coefficient $\left(\mathrm{P}_{\mathrm{Ca}} / \mathrm{P}_{\mathrm{M}}\right)$, referred to as intrinsic permeability [62]:

$$
\mathrm{E}_{\mathrm{rev}}=\frac{\mathrm{RT}}{2 \mathrm{~F}} \ln \frac{4 \mathrm{P}_{\mathrm{Ca}}\left[\mathrm{Ca}^{2+}\right]_{\mathrm{C}}+\mathrm{P}_{\mathrm{K}}\left[\mathrm{K}^{+}\right]_{\mathrm{C}}+\mathrm{P}_{\text {Tris }}\left[\text { Tris }^{+}\right]_{\mathrm{C}}}{4 \mathrm{P}_{\mathrm{Ca}}\left[\mathrm{Ca}^{2+}\right]_{\mathrm{L}}+\mathrm{P}_{\mathrm{K}}\left[\mathrm{K}^{+}\right]_{\mathrm{L}}+\mathrm{P}_{\text {Tris }}\left[\text { Tris }^{+}\right]_{\mathrm{L}}+4 \mathrm{P}_{\mathrm{M}}\left[\mathrm{M}^{2+}\right]_{\mathrm{L}}},
$$

Equation (1) is derived from the well-known Goldman-Hodgkin-Katz (GHK) equation $[63,64]$; where $\mathrm{F}$ is Faraday's constant, $\mathrm{R}$ is the universal gas constant and $\mathrm{T}$ is the absolute temperature. At room temperature $\left(25^{\circ} \mathrm{C}\right), \mathrm{RT} / \mathrm{F}$ is $\sim 25.693 \mathrm{mV}$. The values of $\mathrm{P}_{\mathrm{Ca}} / \mathrm{P}_{\text {Tris }}$ and $\mathrm{P}_{\mathrm{Ca}} / \mathrm{P}_{\mathrm{K}}$ were, respectively, $29.545[65]$ and $6.5[46,66]$. The subscripts $\mathrm{C}$ and L denote a cytosolic or luminal quantity, respectively. Similarly, the $\mathrm{E}_{\mathrm{rev}}$ plotted against pure luminal $\mathrm{Ca}^{2+}\left(\left[\mathrm{Ca}^{2+}\right]_{\mathrm{L}}\right)$ was fitted. For visualization purposes, the dependences of $\mathrm{G}$ and $\mathrm{I}_{0}$ on $\left[\mathrm{Ca}^{2+}\right]_{\mathrm{L}}$ were fitted by the Michaelis-Menten equation.

Ion diffusion theory [67] was used to relate the local $\left[\mathrm{Zn}^{2+}\right], \mathrm{Zn}^{2+}$ current amplitude at $0 \mathrm{mV}\left(\mathrm{I}_{0, \mathrm{Zn}}\right)$, and distance from an open channel pore (r) (Equation (2)):

$$
\left[\mathrm{Zn}^{2+}\right](\mathrm{r})=\mathrm{e}^{\frac{-\mathrm{r}}{\sqrt{\frac{\mathrm{D}_{\mathrm{Zn}}}{\mathrm{k}[\mathrm{B}]}}}} \frac{\mathrm{I}_{0, \mathrm{Zn}}}{4 \pi \mathrm{FD}_{\mathrm{Zn}} \mathrm{r}} .
$$

Here, $D_{Z n}=7.03 \times 10^{-10} \mathrm{~m}^{2} \mathrm{~s}^{-1}[68]$ is the diffusion coefficient for $\mathrm{Zn}^{2+}, \mathrm{k}$ is the rate for $\mathrm{Zn}^{2+}$ binding to the buffer $\mathrm{B},[\mathrm{B}]=1 \mathrm{mM}$ is the buffer concentration, $\mathrm{F}=96,500 \mathrm{C} \mathrm{mol}^{-1}$ is the Faraday constant. The only $\mathrm{Zn}^{2+}$ buffer present in most of our experiments was EGTA and its rate of $\mathrm{Zn}^{2+}$ binding, $\mathrm{k}$, was $2.6 \times 10^{6} \mathrm{M}^{-1} \mathrm{~s}^{-1}$ [69].

The results are reported as the average \pm SEM or the fitted value \pm SEM. Statistical comparison of differences in mole-fraction experiments $\left(\mathrm{I}_{0}\right.$ and $\left.\mathrm{G}\right)$ were made by two-way ANOVA with Tukey's post hoc test. We also used one-way ANOVA with Tukey's post hoc test to statistically compare changes in the $\mathrm{pH}$ of solutions when luminal $\mathrm{M}^{2+}$ was added and changes in the values of $\mathrm{T}_{\mathrm{O}}, \mathrm{T}_{\mathrm{C}}$, and $\mathrm{F}$ caused by luminal $\mathrm{Zn}^{2+}$. Unpaired Student's $t$ tests were performed to detect significant changes in the latency of RYR2 activity decay when $\left[\mathrm{Cd}^{2+}\right]_{\mathrm{L}}$ was added and differences in $\mathrm{I}_{0}, \mathrm{E}_{\mathrm{rev}}$, or $\mathrm{G}$ values when $\mathrm{pH}$ was changed. Paired Student's $t$ tests were utilized for statistical comparison of differences in $\mathrm{I}_{0}, \mathrm{E}_{\mathrm{rev}}$, or G values when $8 \mathrm{mM}\left[\mathrm{Zn}^{2+}\right]_{\mathrm{L}}$ or $8 \mathrm{mM}\left[\mathrm{Cd}^{2+}\right]_{\mathrm{L}}$ was mixed with $8 \mathrm{mM}\left[\mathrm{Ca}^{2+}\right]_{\mathrm{L}}$, and changes 
in $\mathrm{P}_{\mathrm{O}}$ when NTA or TPEN was added to chelate $\mathrm{Zn}^{2+}$ in the cytosolic solution. Differences were regarded to be statistically significant at $p<0.05$.

\section{Results}

RYR2 channels isolated from rat hearts were incorporated into the BLMs and recorded under voltage clamp conditions. The goal here was to measure the RYR2 current carried by $\mathrm{Zn}^{2+}$ in the lumen-to-cytosol direction. Data are presented that define permeation and gating properties including the intrinsic $\mathrm{Zn}^{2+}$ permeability of the RYR2 channel. Additionally, a potential role of the RYR2 $\mathrm{Zn}^{2+}$ current in local $\mathrm{Zn}^{2+}$ signaling was assessed by computing $\mathrm{Zn}^{2+}$ accumulation near potential molecular targets, such as neighboring RYR2 channels and the $\mathrm{Zn}^{2+}$ finger domain extending into the cytosolic vestibular portion of the RYR2 permeation pathway [55]. Finally, the ability of $\mathrm{Cd}^{2+}$ current in the lumen-to-cytosol direction to displace $\mathrm{Zn}^{2+}$ from the $\mathrm{RYR} 2 \mathrm{Zn}^{2+}$ finger was investigated.

Working with $\mathrm{Zn}^{2+}$ compounds is usually difficult, because they show a low solubility in water at the physiologically-relevant $\mathrm{pH}$ range [70,71]. We therefore tested more $\mathrm{Zn}^{2+}$ compounds and found that the chloride salt of $\mathrm{Zn}^{2+}$ was most appropriate for our purpose. In addition, $8 \mathrm{mM} \mathrm{ZnCl} 2$ was the maximal concentration available for testing to avoid formation of precipitates and thus prevent overestimation of the $\mathrm{Zn}^{2+}$ content. Of note, $\mathrm{K}^{+}$and Tris $^{+}$cations were also added to the solutions, although both permeate the RYR2 channel [65] and could potentially interfere with RYR2 permeation properties for $\mathrm{Zn}^{2+}$ cations. However, they were added symmetrically to both RYR2 sides to diminish their contributions. Since only the chloride salt of $\mathrm{Zn}^{2+}$ could have been used, a small $\mathrm{Cl}^{-}$ gradient ( $50 \mathrm{mM}$ vs. $58-66 \mathrm{mM}$ ) was inevitably generated at $0 \mathrm{mV}$ by $\mathrm{Zn}^{2+}$ additions to the luminal solution, thus providing a driving force for $\mathrm{Cl}^{-}$transport through the BLM. Despite the presence of $\mathrm{Cl}^{-}$channels in cardiac SR microsomes, we did not observe their activity under the conditions utilized in our study. The reason for this probably lies in the fact that $\mathrm{Cl}^{-}$gradient was not sufficient to produce recordable $\mathrm{Cl}^{-}$currents. Another possibility is that $\mathrm{Cl}^{-}$channels were not incorporated into the BLMs together with RYR2 channels.

\subsection{The RYR2 Conductance for $\mathrm{Zn}^{2+}$}

Our initial aim was to directly record the $\mathrm{Zn}^{2+}$ current by building the $\mathrm{Zn}^{2+}$ gradient across the BLM. However, after several unsuccessful attempts to reconstitute RYR2 channels with $\mathrm{Zn}^{2+}$ in the luminal solution, we modified our experimental approach. The luminal compartment was perfused with the $\mathrm{Zn}^{2+}$ solution after RYR2 channels were incorporated into the BLMs in the presence of $8 \mathrm{mM}\left[\mathrm{Ca}^{2+}\right]_{\mathrm{L}}$. Representative $\mathrm{RYR} 2$ recordings measured in the presence of $8 \mathrm{mM}\left[\mathrm{Zn}^{2+}\right]_{\mathrm{L}}$ are shown in Figure 1A. The channels were solely activated by $6-7 \mathrm{mM}$ cytosolic caffeine in the presence of non-activating free $\left[\mathrm{Ca}^{2+}\right]_{\mathrm{C}}(90 \mathrm{nM})$ to record the longer and fully resolved open and closed channel events required for the unbiased determination of the $\mathrm{Zn}^{2+}$ current values $\left(\mathrm{I}_{\mathrm{Zn}}\right)$. When the membrane voltage changed in $5 \mathrm{mV}$ incremental steps from $-10 \mathrm{mV}$ to $+10 \mathrm{mV}$, the RYR2 $\mathrm{I}_{\mathrm{Zn}}$ increased from $0.31 \pm 0.15 \mathrm{pA}$ to $1.86 \pm 0.16 \mathrm{pA}$. At $0 \mathrm{mV}$, the typical value of $\mathrm{I}_{0, \mathrm{Zn}}$ was $0.927 \pm 0.093 \mathrm{pA}$. To estimate $\mathrm{Zn}^{2+}$ conductance $\left(\mathrm{G}_{\mathrm{Zn}}\right)$, linear regression was performed on the current-voltage relationship (Figure 1B). Under asymmetrical conditions when the pure $\mathrm{Zn}^{2+}$ current was driven by the $8 \mathrm{mM}$ gradient, the value of $\mathrm{G}_{\mathrm{Zn}}$ was $81.1 \pm 2.4 \mathrm{pS}$. Moreover, the reversal potential $\left(\mathrm{E}_{\text {rev }}\right)$ was $-11.8 \pm 1.1 \mathrm{mV}$. 
A

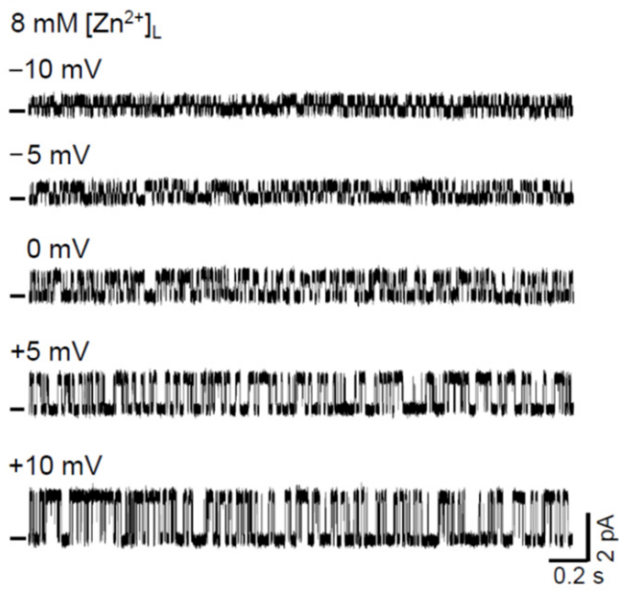

B

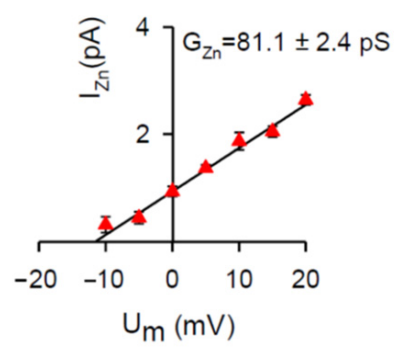

Figure 1. The RYR2 channel is permeable to $\mathrm{Zn}^{2+}$. (A) Representative RYR2 currents (digitally filtered at $250-400 \mathrm{~Hz}$ ), shown as upward deflections from the marked zero-current level, in the presence of $8 \mathrm{mM}\left[\mathrm{Zn}^{2+}\right]_{\mathrm{L}}$ when $\mathrm{Zn}^{2+}$ was only the charge carrier. Current recordings were conducted at -10 , $-5,0,+5,+10 \mathrm{mV}$ and are from the same channel. RYR2 channels were activated by $6-7 \mathrm{mM}$ caffeine in the presence of $90 \mathrm{nM}$ free $\left[\mathrm{Ca}^{2+}\right]_{C}$. (B) Current-voltage relationship of the RYR2 channel was well-fitted by a straight line with the $\mathrm{G}_{\mathrm{Zn}}$ value of $81.1 \pm 2.4 \mathrm{pS}$. Data shown are average $\pm \mathrm{SEM}$ of 5-7 experiments and error bars are shown only when SEM is larger than symbol size.

\subsection{Mole-Fraction Experiments under Non-Saturating Conditions}

To evaluate the $\mathrm{Zn}^{2+}$ permeability coefficient relative to $\mathrm{Ca}^{2+}$, we investigated the mole-fraction behavior of $\mathrm{I}_{0}, \mathrm{E}_{\mathrm{rev}}$, and $\mathrm{G}$ in the following $\mathrm{Zn}^{2+} / \mathrm{Ca}^{2+}$ mixtures on RYR2 luminal face. Particularly, 4, 5, 6 and $7 \mathrm{mM}\left[\mathrm{Zn}^{2+}\right]_{\mathrm{L}}$ was mixed with 4, 3, 2 and $1 \mathrm{mM}$ $\left[\mathrm{Ca}^{2+}\right]_{\mathrm{L}}$, respectively. We focused on the luminal solutions with the highest mole fraction of $\mathrm{Zn}^{2+}$ because if there were differences from the control $\left(1-8 \mathrm{mM}\left[\mathrm{Ca}^{2+}\right]_{\mathrm{L}}\right)$, they should be the most pronounced. Figure 2 depicts the representative RYR2 recordings at $0 \mathrm{mV}$ in the control and when luminal $\mathrm{Zn}^{2+}$ was present. RYR2 channels were moderately activated by $1-2 \mathrm{mM}$ caffeine and only for $8 \mathrm{mM}\left[\mathrm{Zn}^{2+}\right]_{\mathrm{L}}$, caffeine concentration was increased to 6-7 mM because luminal $\mathrm{Ca}^{2+}$, in contrast with other divalent cations, has been shown to be a strong sensitizer of the RYR2 channel to caffeine [50,51]. Since RYR2 gating is also strongly affected by luminal $\mathrm{Ca}^{2+}$ [51], the RYR2 channel exhibited a much faster gating, manifested by the increased number of open and closed events at the similar channel activity when only $8 \mathrm{mM}\left[\mathrm{Zn}^{2+}\right]_{\mathrm{L}}$ was present (Figure 2). At the quantitative level, this finding was supported by gating parameter calculations. Results collected for the frequency of opening $(\mathrm{F})$, average open $\left(\mathrm{T}_{\mathrm{O}}\right)$ and closed $\left(\mathrm{T}_{\mathrm{C}}\right)$ times are summarized in Table 1 . The $\mathrm{F}$ value was increased more than three-fold when $8 \mathrm{mM}\left[\mathrm{Ca}^{2+}\right]_{\mathrm{L}}$ was completely replaced by $8 \mathrm{mM}$ $\left[\mathrm{Zn}^{2+}\right]_{\mathrm{L}}$. Because $\mathrm{F}$ is the reciprocal of a summation of $\mathrm{T}_{\mathrm{O}}$ and $\mathrm{T}_{\mathrm{C}}$, a significant shortening in both $\mathrm{T}_{\mathrm{O}}$ and $\mathrm{T}_{\mathrm{C}}$ was observed. As we expected, the presence of even $1 \mathrm{mM}\left[\mathrm{Ca}^{2+}\right]_{\mathrm{L}}$ precluded any change in RYR2 gating behavior when luminal $\mathrm{Zn}^{2+}$ was added. This is fully consistent with findings gained for various mixtures of luminal $\mathrm{Mg}^{2+}$ or $\mathrm{Ba}^{2+}$ with $\mathrm{Ca}^{2+}[51]$, thus further highlighting a specific ability of luminal $\mathrm{Ca}^{2+}$ to slow down RYR2 gating. Moreover, no appreciable differences were noted in all three gating parameters calculated for $8 \mathrm{mM}\left[\mathrm{Zn}^{2+}\right]_{\mathrm{L}}$ and $8 \mathrm{mM}\left[\mathrm{Mg}^{2+}\right]_{\mathrm{L}}$, similar to that found previously for luminal $\mathrm{Mg}^{2+}$ and $\mathrm{Ba}^{2+}[51]$. 


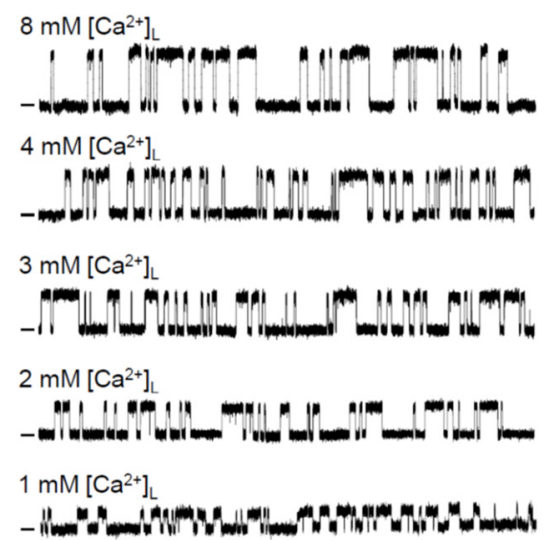

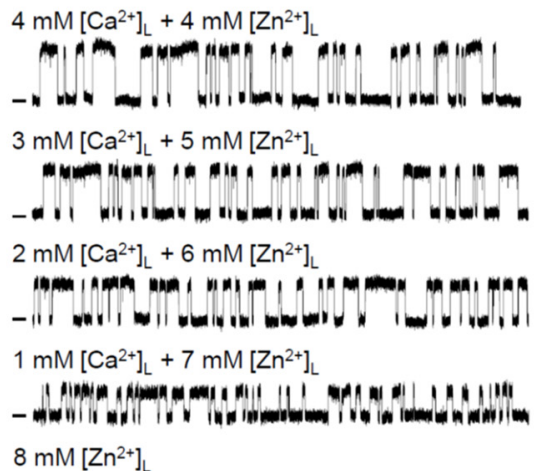

Figure 2. Luminal $\mathrm{Zn}^{2+}$ mixed with $\mathrm{Ca}^{2+}$ increases $\mathrm{RYR} 2$ currents under non-saturating conditions. Representative RYR2 currents (digitally filtered at 250-400 Hz), shown as upward deflections from the marked zero-current level, in the absence (control, left five traces) and after luminal $\mathrm{Zn}^{2+}$ exposure (right five traces). In total, 4, 5, 6, $7 \mathrm{mM}\left[\mathrm{Zn}^{2+}\right]_{\mathrm{L}}$ was added to $4,3,2,1 \mathrm{mM}\left[\mathrm{Ca}^{2+}\right]_{\mathrm{L}}$ (control), respectively, to keep the total divalent concentration constant at $8 \mathrm{mM}$. Representative RYR2 recordings for pure $8 \mathrm{mM}\left[\mathrm{Ca}^{2+}\right]_{\mathrm{L}}$ (control) and $8 \mathrm{mM}\left[\mathrm{Zn}^{2+}\right]_{\mathrm{L}}$ are also shown. RYR2 channels were activated by $1-2 \mathrm{mM}$ caffeine in the presence of $90 \mathrm{nM}$ free $\left[\mathrm{Ca}^{2+}\right]_{\mathrm{C}}$. In the presence of $8 \mathrm{mM}\left[\mathrm{Zn}^{2+}\right]_{\mathrm{L}}$, caffeine concentration was increased to 6-7 mM. Current recordings were conducted at $0 \mathrm{mV}$ and are from different channels.

Table 1. Effects of luminal $\mathrm{M}^{2+}\left(\mathrm{M}^{2+}: \mathrm{Mg}^{2+}, \mathrm{Zn}^{2+}\right.$ or $\left.\mathrm{Ca}^{2+}\right)$ on gating parameters of the RYR2 channel at $\mathrm{P}_{\mathrm{O}} \sim 0.5$.

\begin{tabular}{|c|c|c|c|c|}
\hline Luminal $\mathbf{M}^{2+}$ & $\mathbf{P}_{\mathrm{O}}$ & $\begin{array}{c}F \\
(\mathrm{~Hz})\end{array}$ & $\begin{array}{c}\mathrm{T}_{\mathrm{O}} \\
\text { (ms) }\end{array}$ & $\begin{array}{c}\mathrm{T}_{\mathrm{C}} \\
(\mathrm{ms})\end{array}$ \\
\hline $8 \mathrm{mM}\left[\mathrm{Ca}^{2+}\right]_{\mathrm{L}}$ & $0.4947 \pm 0.0059$ & $10.29 \pm 1.04^{\#}$ & $49.03 \pm 4.73^{\#}$ & $49.81 \pm 7.04 \#$ \\
\hline $8 \mathrm{mM}\left[\mathrm{Mg}^{2+}\right]_{\mathrm{L}}$ & $0.5137 \pm 0.0040$ & $38.4 \pm 2.4 *$ & $13.54 \pm 0.77 *$ & $12.94 \pm 0.99 *$ \\
\hline $8 \mathrm{mM}\left[\mathrm{Zn}^{2+}\right]_{\mathrm{L}}$ & $0.526 \pm 0.010$ & $36.99 \pm 1.03 *$ & $14.74 \pm 0.64$ * & $12.17 \pm 0.51$ * \\
\hline $1 \mathrm{mM}\left[\mathrm{Ca}^{2+}\right]_{\mathrm{L}}+7 \mathrm{mM}\left[\mathrm{Zn}^{2+}\right]_{\mathrm{L}}$ & $0.495 \pm 0.015$ & $11.43 \pm 0.66^{\#}$ & $41.8 \pm 1.7^{\#}$ & $45.22 \pm 4.37^{\#}$ \\
\hline
\end{tabular}

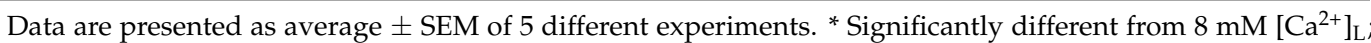
\# significantly different from $8 \mathrm{mM}\left[\mathrm{Zn}^{2+}\right]_{\mathrm{L}}$ (one-way ANOVA with Tukey's post hoc test).

Further, it is evident from the raw current traces that for all tested $\mathrm{Zn}^{2+}$ additions the $\mathrm{I}_{0}$ substantially increased (Figure 2). The averaged results are presented in Figure 3A (middle panel). In the control, the $\mathrm{I}_{0}$ grew with increasing $\left[\mathrm{Ca}^{2+}\right]_{\mathrm{L}}$. The dependence of $\mathrm{I}_{0}$ on $\left[\mathrm{Ca}^{2+}\right]_{\mathrm{L}}$ was well fitted by the Michaelis-Menten equation. The significant increase in $\mathrm{I}_{0}$ by $\sim 45 \%$ and $\sim 100 \%$ was caused by the addition of $6 \mathrm{mM}$ and $7 \mathrm{mM}\left[\mathrm{Zn}^{2+}\right]_{\mathrm{L}}$, respectively. For lower $\left[\mathrm{Zn}^{2+}\right]_{\mathrm{L}}$, an increasing trend was also detected; however, it did not achieve significance. To demonstrate the validity and reliability of our $\mathrm{Zn}^{2+}$ measurements, we generated the same dataset for $\mathrm{Mg}^{2+}$ and $\mathrm{Ca}^{2+}$ (chloride salts). $\mathrm{Mg}^{2+}$ and $\mathrm{Zn}^{2+}$ share the intrinsic physical properties such as ionic size, charge density and hydration enthalpy (Table 2) relevant to permeation through ion channels [52-54]; therefore, we would expect similar passage of these cations through the RYR2 pore. As the positive control, varied $\mathrm{CaCl}_{2}$ concentrations were added to the luminal RYR2 side to reach the total $8 \mathrm{mM}\left[\mathrm{Ca}^{2+}\right]_{\mathrm{L}}$. Here, $\mathrm{M}^{2+}$ stands for $\mathrm{Mg}^{2+}, \mathrm{Zn}^{2+}$ or $\mathrm{Ca}^{2+}$ for simplicity. Luminal $\mathrm{Zn}^{2+}$ had less ability to affect $\mathrm{I}_{0}$ carried by $\mathrm{Ca}^{2+}$ than luminal $\mathrm{Mg}^{2+}$. This was particularly noted when $7 \mathrm{mM}$ $\left[\mathrm{Mg}^{2+}\right]_{\mathrm{L}}$ caused more than three-fold increase in the RYR2 current driven by the $1 \mathrm{mM} \mathrm{Ca}^{2+}$ gradient (Figure 3A, left panel). Lower $\left[\mathrm{Mg}^{2+}\right]_{\mathrm{L}}$ had a smaller but still significant impact. Because the RYR2 $\mathrm{I}_{0}$ was considerably lower when $8 \mathrm{mM}\left[\mathrm{Ca}^{2+}\right]_{\mathrm{L}}$ was replaced by $8 \mathrm{mM}$ $\left[\mathrm{Mg}^{2+}\right]_{\mathrm{L}}$, the dominance of $\mathrm{Mg}^{2+}(6-7 \mathrm{mM})$ in the mixture with $\mathrm{Ca}^{2+}$ was not sufficient to reach the value of $\mathrm{I}_{0}$ with pure $8 \mathrm{mM}\left[\mathrm{Ca}^{2+}\right]_{\mathrm{L}}$. Therefore, only the $\mathrm{Ca}^{2+}$ additions (chloride 
salt) caused such a large increase that the $\mathrm{I}_{0}$ values became similar to those obtained for both $8 \mathrm{mM} \mathrm{Ca}(\mathrm{OH})_{2}(2.835 \pm 0.094 \mathrm{pA})$ and $8 \mathrm{mM} \mathrm{CaCl}_{2}(2.69 \pm 0.11 \mathrm{pA})$ (Figure 3A, right panel). $\mathrm{I}_{0}$ data indicate that the RYR2 channel apparently has a lower conductance and intrinsic permeability for $\mathrm{Zn}^{2+}$ than for $\mathrm{Ca}^{2+}$ and $\mathrm{Mg}^{2+}$.

Table 2. Physical characteristics of divalent cations implicated in permeation through ion channels.

\begin{tabular}{cccc}
\hline Divalent Cation & $\begin{array}{c}\text { Ionic Radius } \\
(\mathbf{p m})\end{array}$ & $\begin{array}{c}\text { Charge Density } \mathbf{b} \\
\left(\mathbf{C} \mathbf{~ m m}^{-3} \mathbf{)}\right.\end{array}$ & $\begin{array}{c}\text { Enthalpy of Hydration }^{\mathbf{c}} \\
\left(\mathbf{k J ~ m o l} \mathbf{~ m o l}^{-\mathbf{1}}\right)\end{array}$ \\
\hline $\mathrm{Ca}^{2+}$ & 99 & 79 & -1577 \\
$\mathrm{Mg}^{2+}$ & 65 & 278 & -1921 \\
$\mathrm{Zn}^{2+}$ & 71 & 214 & -2046 \\
$\mathrm{Cd}^{2+}$ & 91 & 102 & -1807 \\
\hline
\end{tabular}

a Ionic radius taken from [72]. ${ }^{b}$ Charge density was calculated according to the formula $2 \mathrm{e} /(4 / 3) \pi \mathrm{r}^{3}$, where $\mathrm{r}$ is the ionic radius and e is $1.602 \times 10^{-19} \mathrm{C} .{ }^{c}$ Enthalpy of hydration taken from [73].

We tested this possibility by determining $E_{\text {rev }}$ and $G$ from current-voltage relationships when the membrane voltage changed in $5 \mathrm{mV}$ incremental steps from $-20 \mathrm{mV}$ to $+20 \mathrm{mV}$. All collected current-voltage plots were Ohmic (data not shown) and well fitted by a straight line. In the control, the $E_{\text {rev }}$ values substantially decreased with raising $\left[\mathrm{Ca}^{2+}\right]_{\mathrm{L}}$ from $1 \mathrm{mM}$ to $8 \mathrm{mM}$ (Figure 3B). Equation (1) well reproduces the luminal $\mathrm{Ca}^{2+}$-dependence of $\mathrm{E}_{\mathrm{rev}}$, thus validating the accuracy of our $\mathrm{E}_{\mathrm{rev}}$ determination. When luminal $\mathrm{Zn}^{2+}$ was added, the $E_{\text {rev }}$ decreased, as expected for the addition of permeant cation, while $E_{\text {rev }}$ for pure $8 \mathrm{mM}\left[\mathrm{Zn}^{2+}\right]_{\mathrm{L}}$ was $-11.8 \pm 1.1 \mathrm{mV}$ (Figure $3 \mathrm{~B}$, middle panel). To estimate the intrinsic $\mathrm{Zn}^{2+}$ permeability of the RYR2 channel, the dependence of $\mathrm{E}_{\mathrm{rev}}$ on a composition of $\mathrm{Zn}^{2+} / \mathrm{Ca}^{2+}$ mixture was then fitted by Equation (1) yielding the relative $\mathrm{Ca}^{2+} / \mathrm{Zn}^{2+}$ permeability coefficient of $2.65 \pm 0.19\left(\mathrm{P}_{\mathrm{Ca}} / \mathrm{P}_{\mathrm{Zn}}\right)$. In comparison, the $\mathrm{E}_{\mathrm{rev}}$ data collected for $\mathrm{Mg}^{2+} / \mathrm{Ca}^{2+}$ mixtures were well fitted with Equation (1) when $\mathrm{P}_{\mathrm{Ca}} / \mathrm{P}_{\mathrm{Mg}}$ was $1.146 \pm 0.071$ (Figure 3B, left panel). This is in good agreement with the intrinsic $\mathrm{Mg}^{2+}$ permeability reported for the RYR2 channel [46]. As expected, the $\mathrm{E}_{\mathrm{rev}}$ measured in $\mathrm{Ca}^{2+} / \mathrm{Ca}^{2+}$ mixtures did not depend on a mixture composition because $8 \mathrm{mM}\left[\mathrm{Ca}^{2+}\right]_{\mathrm{L}}$ was always present on the RYR2 luminal face. The fitted value for $\mathrm{P}_{\mathrm{Ca}} / \mathrm{P}_{\mathrm{Ca}}$ was equal to $1.035 \pm 0.061$ (Figure 3B, right panel).

In general, ion translocation through the channel pore is characterized by a specific conductance, therefore, we examined $\mathrm{G}$ as a function of the $\mathrm{Zn}^{2+} / \mathrm{Ca}^{2+}$ mixture composition (Figure 3C, middle panel). For the pure luminal $\mathrm{Ca}^{2+}$ solutions, the $\mathrm{G}$ values plotted against $\left[\mathrm{Ca}^{2+}\right]_{\mathrm{L}}$ were fitted by the Michaelis-Menten equation with almost full saturation at $8 \mathrm{mM}$ $\left[\mathrm{Ca}^{2+}\right]_{\mathrm{L}}$ (Figure $3 \mathrm{C}$ ). When luminal $\mathrm{Zn}^{2+}$ was added, we revealed a significant increase in $\mathrm{G}$ only for the addition of $7 \mathrm{mM}\left[\mathrm{Zn}^{2+}\right]_{\mathrm{L}}$ to $1 \mathrm{mM}\left[\mathrm{Ca}^{2+}\right]_{\mathrm{L}}$ (Figure $3 \mathrm{C}$, middle panel), evidently because of the weaker intrinsic $\mathrm{Zn}^{2+}$ permeability $\left(\mathrm{P}_{\mathrm{Ca}} / \mathrm{P}_{\mathrm{Zn}}=2.65 \pm 0.19\right)$ and a significantly lower RYR2 conductance for $\mathrm{Zn}^{2+}\left(81.1 \pm 2.4 \mathrm{pS}\right.$ for $8 \mathrm{mM}\left[\mathrm{Zn}^{2+}\right]_{\mathrm{L}} \mathrm{vs}$. $127.5 \pm 1.8 \mathrm{pS}$ for $\left.8 \mathrm{mM}\left[\mathrm{Ca}^{2+}\right]_{\mathrm{L}}\right)$. The situation for luminal $\mathrm{Mg}^{2+}$ was slightly different because the $\mathrm{Mg}^{2+}$ additions resulted in a greater change in the $\mathrm{G}$ values (Figure 3C, left panel). This was despite that the RYR2 channel exhibited a significantly lower $\mathrm{G}_{\text {for }} \mathrm{Mg}^{2+}$ than for $\mathrm{Ca}^{2+}$ when testing $8 \mathrm{mM}$ gradients $(95.3 \pm 1.4 \mathrm{pS}$ vs. $127.5 \pm 1.8 \mathrm{pS}$, respectively). When luminal $\mathrm{Ca}^{2+}$ was added, two identical cations were mixed, and therefore the $\mathrm{G}$ values were not changed (Figure $3 C$, right panel). In summary, the $I_{0}, G$ and $E_{\text {rev }}$ results collectively indicate that the passage of $\mathrm{Zn}^{2+}$ through the RYR2 channel is less effective than even for $\mathrm{Mg}^{2+}$, despite having similar physical properties (Table 2). 

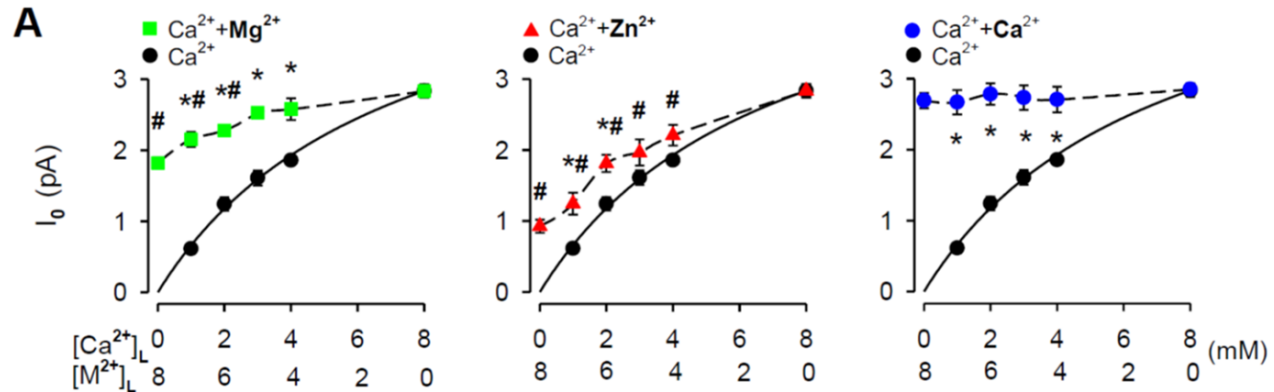

B
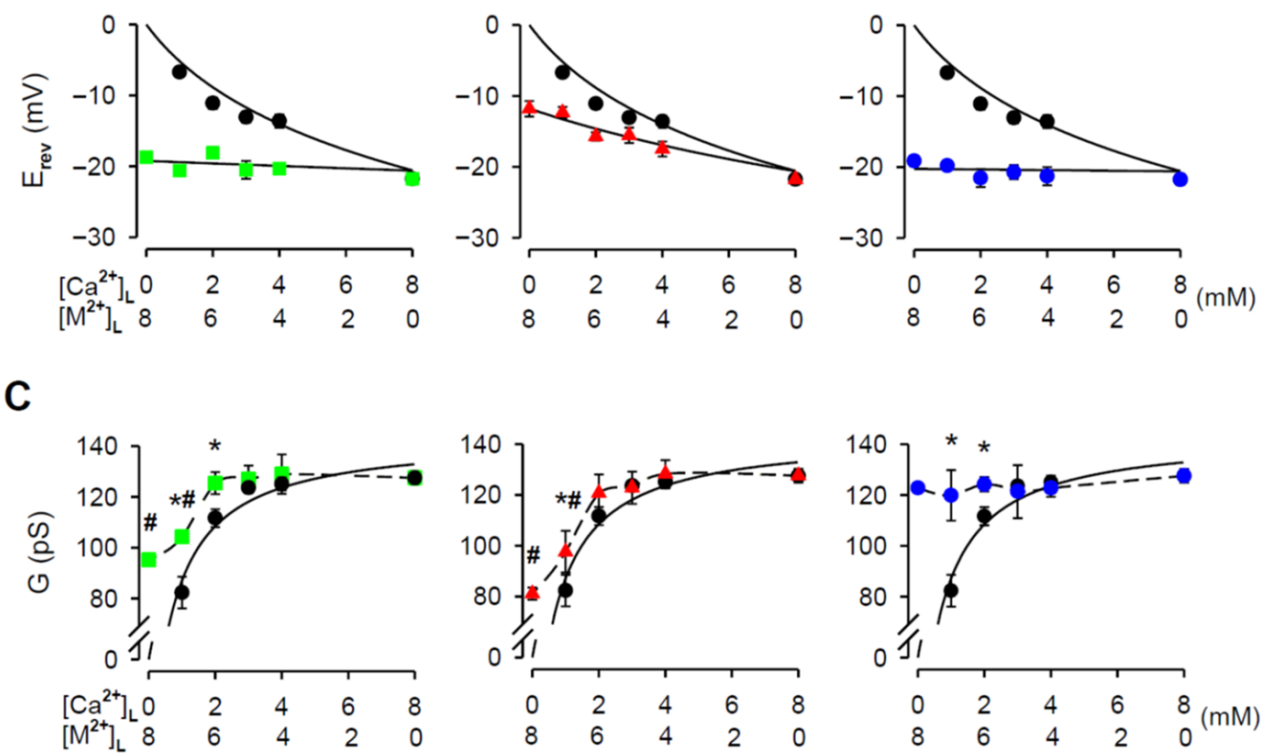

Figure 3. $\mathrm{M}^{2+} / \mathrm{Ca}^{2+}$ mole-fraction experiments under non-saturating conditions. The $\mathrm{I}_{0}(\mathrm{~A}), \mathrm{E}_{\mathrm{rev}}$ (B), and G (C) plotted against a composition of $\mathrm{M}^{2+} / \mathrm{Ca}^{2+}$ mixture on the RYR2 luminal face $\left(\mathrm{M}^{2+}\right.$ : $\mathrm{Mg}^{2+}$-green square, $\mathrm{Zn}^{2+}$-red triangle, or $\mathrm{Ca}^{2+}$-blue circle). In total, 4, 5, 6, $7 \mathrm{mM}\left[\mathrm{M}^{2+}\right]_{\mathrm{L}}$ was added to $4,3,2,1 \mathrm{mM}\left[\mathrm{Ca}^{2+}\right]_{\mathrm{L}}$, respectively, to keep the total divalent concentration constant at $8 \mathrm{mM}$. Data obtained for pure $8 \mathrm{mM}\left[\mathrm{M}^{2+}\right]_{\mathrm{L}}$ are also included. As the control, the $\left[\mathrm{Ca}^{2+}\right]_{\mathrm{L}}$-dependence of $\mathrm{E}_{\mathrm{rev}}, \mathrm{G}$ and $\mathrm{I}_{0}$ is shown (black circle). ${ }^{*}$ Significantly different from the respective control values;

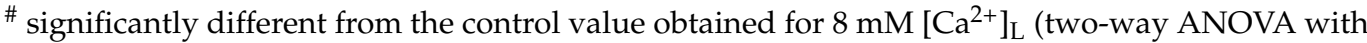
Tukey's post hoc test). The solid lines in (B) are the best fits using Equation (1) and in (A) and (C) using the Michaelis-Menten equation. The dashed lines in (A) and (C) are drawn point to point. Data shown are average \pm SEM of 5-15 experiments and error bars are shown only when SEM is larger than symbol size.

\subsection{Effects of $\mathrm{pH}$ When Luminal $\mathrm{Zn}^{2+}$ Was Added}

The chloride salt of $\mathrm{Zn}^{2+}$ has been reported to change the $\mathrm{pH}$ of solutions because it is a weak acid [74]. Such changes could substantially affect measurements of the RYR2 $\mathrm{G}$ and intrinsic permeability $[75,76]$. To evaluate this potential source of inaccuracy, we first investigated the effects of the $\mathrm{Zn}^{2+}$ additions on the $\mathrm{pH}$ of the luminal solutions, while retaining the same volumes used for the single-channel recordings. $\mathrm{Mg}^{2+}$ and $\mathrm{Ca}^{2+}$ were examined in a similar manner. The summary data are plotted as a function of $\mathrm{M}^{2+} / \mathrm{Ca}^{2+}$ mixture content in Figure $4 \mathrm{~A}$. While $\mathrm{Mg}^{2+}$ and $\mathrm{Ca}^{2+}$ additions $(4-7 \mathrm{mM})$ induced no significant changes in the $\mathrm{pH}$ from the control, luminal $\mathrm{Zn}^{2+}$ had a substantial effect with increasing its mole fraction. The $\mathrm{pH}$ of the luminal solution with no $\mathrm{Ca}^{2+}$ present $(10 \mathrm{mM}$ Tris, $20 \mathrm{mM}$ HEPES, $50 \mathrm{mM} \mathrm{KCl}$ ) dropped from $7.34 \pm 0.007$ to $6.83 \pm 0.017$ when $8 \mathrm{mM}$ $\left[\mathrm{Zn}^{2+}\right]_{\mathrm{L}}$ was added. In contrast, there was no $\mathrm{pH}$ change with $8 \mathrm{mM}\left[\mathrm{Mg}^{2+}\right]_{\mathrm{L}}$ or $\left[\mathrm{Ca}^{2+}\right]_{\mathrm{L}}$. Importantly, experimental conditions with $8 \mathrm{mM}\left[\mathrm{Zn}^{2+}\right]_{\mathrm{L}}$ were limited to a lower $\mathrm{pH}$ of 
6.83 because, otherwise, $\mathrm{Zn}^{2+}$ precipitates occurred. To test if the large decrease in $\mathrm{pH}$ observed for the addition of $8 \mathrm{mM}\left[\mathrm{Zn}^{2+}\right]_{\mathrm{L}}$ might produce a shift in $\mathrm{I}_{0}, \mathrm{E}_{\mathrm{rev}}$ and $\mathrm{G}$ values, we tested $8 \mathrm{mM}\left[\mathrm{Ca}^{2+}\right]_{\mathrm{L}}$ (hydroxide) buffered to $\mathrm{pH}$ values of 6.83 and 7.35. Summary results presented in Figure 4B show that $\mathrm{pH}$ decrease was essentially without any significant effect. These data indicate that all results of mole-fraction experiments collected for luminal $\mathrm{Zn}^{2+}$ can be indeed interpreted as a manifestation of the intrinsic $\mathrm{Zn}^{2+}$ permeability displayed by the RYR2 channel.

A

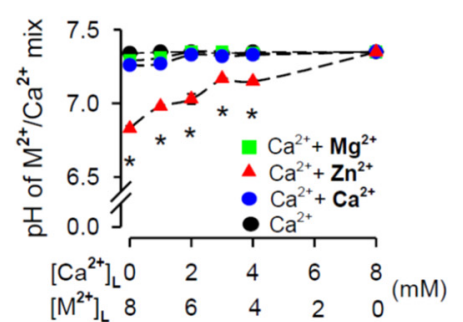

B

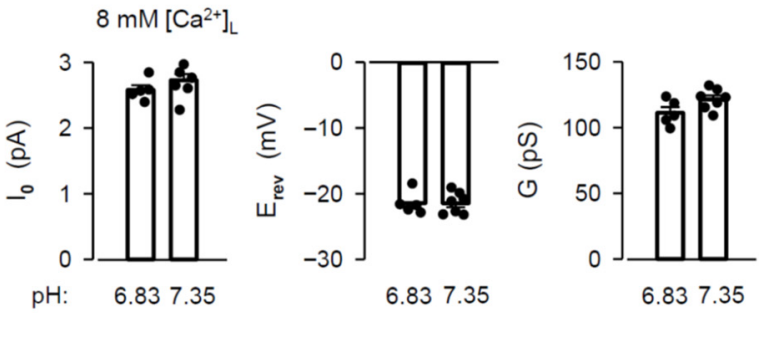

Figure 4. Changes in $\mathrm{pH}$ caused by the $\mathrm{Zn}^{2+}$ additions have no effects on $\mathrm{RYR} 2$ permeation properties. (A) Effects of the $\mathrm{M}^{2+}$ additions on $\mathrm{pH}$ of $\mathrm{M}^{2+} / \mathrm{Ca}^{2+}$ mixture $\left(\mathrm{M}^{2+}: \mathrm{Mg}^{2+}\right.$-green square, $\mathrm{Zn}^{2+}-$ red triangle, or $\mathrm{Ca}^{2+}$-blue circle). In total, $4-7 \mathrm{mM}\left[\mathrm{M}^{2+}\right]_{\mathrm{L}}$ was added to $1-4 \mathrm{mM}\left[\mathrm{Ca}^{2+}\right]_{\mathrm{L}}$, keeping the total divalent concentration constant at $8 \mathrm{mM}$. As the control, the $\left[\mathrm{Ca}^{2+}\right]_{\mathrm{L}}$-dependence of $\mathrm{pH}$ is shown

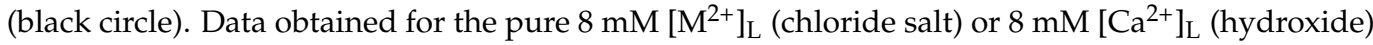
are also included. ${ }^{*}$ Significantly different from the respective control values (one-way ANOVA with Tukey's post hoc test). (B) The $\mathrm{I}_{0}, \mathrm{E}_{\mathrm{rev}}$ and $\mathrm{G}$ values obtained for $\mathrm{pH}$ of 6.83 and 7.35 when $8 \mathrm{mM}$ $\left[\mathrm{Ca}^{2+}\right]_{\mathrm{L}}$ (hydroxide) was present (unpaired Student's $t$ test). Data shown are average \pm SEM of 5-7 experiments, and error bars in (A) are shown only when SEM is larger than symbol size. Data points shown in (B) are individual measurements.

\subsection{Effects of Luminal $\mathrm{Zn}^{2+}$ on RYR2 Permeation Properties under Near-Saturating Conditions}

As seen in Figure $3 \mathrm{C}$, the $\left[\mathrm{Ca}^{2+}\right]_{\mathrm{L}}$-dependence of the RYR2 G almost saturated at $8 \mathrm{mM}$. This indicates that all mole-fraction experiments shown in Figure 3 were performed at $\left[\mathrm{Ca}^{2+}\right]_{\mathrm{L}}$, which is not at the saturating portion of the $\mathrm{G}-\left[\mathrm{Ca}^{2+}\right]_{\mathrm{L}}$ curve. Under such conditions, luminal $\mathrm{Zn}^{2+}$ would not strongly compete with $\mathrm{Ca}^{2+}$ for occupancy of the RYR2 pore, if at all $[77,78]$. To further examine the mechanisms of $\mathrm{Zn}^{2+}$ permeation, we extended the $\mathrm{I}_{0}, \mathrm{E}_{\text {rev }}$ and $\mathrm{G}$ measurements to include near-saturating conditions. Because $8 \mathrm{mM}$ concentration was the highest possible $\left[\mathrm{Zn}^{2+}\right]_{\mathrm{L}}$ available for testing, we could use only a mixture with $8 \mathrm{mM}\left[\mathrm{Ca}^{2+}\right]_{\mathrm{L}}$ to allow a reasonable competition between these cations [79]. Figure 5A shows representative current traces of the same caffeine-activated RYR2 channel recorded at $0 \mathrm{mV}$ in the absence and presence of luminal $\mathrm{Zn}^{2+}$. One can see that $8 \mathrm{mM}$ $\left[\mathrm{Zn}^{2+}\right]_{\mathrm{L}}$ slightly reduced the current amplitude carried by $8 \mathrm{mM}\left[\mathrm{Ca}^{2+}\right]_{\mathrm{L}}$. Average results are presented in Figure 5B (left panel). While the reduction in the $\mathrm{I}_{0}$ was small but significant, $E_{\text {rev }}$ changed only negligibly by $\sim-1.35 \mathrm{mV}$ (Figure $5 \mathrm{~B}$, middle panel). This small shift toward more negative values was also predicted by Equation (1) for the estimated $\mathrm{P}_{\mathrm{Ca}} / \mathrm{P}_{\mathrm{Zn}}$ of $2.65 \pm 0.19(-23.97 \mathrm{mV}$ theoretical vs. $-23.59 \pm 1.03 \mathrm{mV}$ experimental). Inevitably, the $\mathrm{G}$ significantly decreased (Figure $5 \mathrm{~B}$, right panel). Of note, the aforementioned changes were not related to $\mathrm{pH}$, although it dropped from $7.35 \pm 0.04$ to $7.058 \pm 0.029$ by the luminal addition of $8 \mathrm{mM}\left[\mathrm{Zn}^{2+}\right]_{\mathrm{L}}$. As shown in Figure $4 \mathrm{~B}$, an even larger decrease in $\mathrm{pH}$ from 7.35 to 6.83 did not produce any significant effect. Taken together, the decrease in $\mathrm{I}_{0}$ and $\mathrm{G}$ values by $\mathrm{Zn}^{2+}$ addition to almost saturating $\left[\mathrm{Ca}^{2+}\right]_{\mathrm{L}}$ could indeed be interpreted as a consequence of competition between two permeant cations inside the RYR2 pore, which exhibits a different intrinsic permeability and/or conductance for each cation. 
A

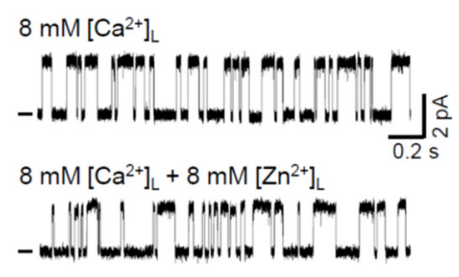

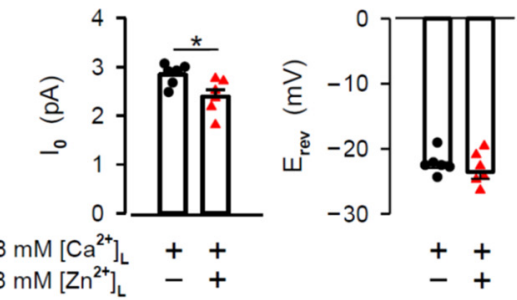

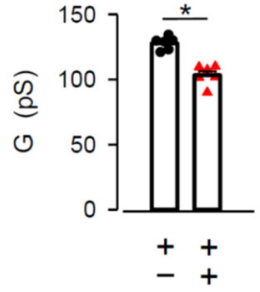

Figure 5. Luminal $\mathrm{Zn}^{2+}$ decreases the RYR2 current under near-saturating conditions. (A) Representative RYR2 currents, shown as upward deflections from the marked zero-current level, for $8 \mathrm{mM}$ $\left[\mathrm{Ca}^{2+}\right]_{\mathrm{L}}$ (control, top trace) and when $8 \mathrm{mM}\left[\mathrm{Zn}^{2+}\right]_{\mathrm{L}}$ was added (bottom trace). RYR2 channels were activated by $1-2 \mathrm{mM}$ caffeine in the presence of $90 \mathrm{nM}$ free $\left[\mathrm{Ca}^{2+}\right]_{C}$. Current recordings were conducted at $0 \mathrm{mV}$ and are from the same channel. (B) The $\mathrm{I}_{0}, \mathrm{E}_{\text {rev }}$ and $\mathrm{G}$ values obtained in the absence and after luminal $\mathrm{Zn}^{2+}$ exposure. * Significantly different from the control values when only luminal $\mathrm{Ca}^{2+}$ was present (paired Student's $t$ test). Data shown are average $\pm \mathrm{SEM}$ of 6 experiments. Data points shown in (B) are individual measurements $\left(\mathrm{Ca}^{2+}\right.$-black circle and $\mathrm{Zn}^{2+} / \mathrm{Ca}^{2+}$-red triangle).

\subsection{The $\mathrm{Zn}^{2+}$ Finger Located within the C-Terminus of the RYR2 Channel as a Potential Target of} the $\mathrm{Zn}^{2+}$ Current

In an attempt to identify a potential target of the RYR2 $\mathrm{Zn}^{2+}$ current, we focused on small protein domains termed the $\mathrm{Zn}^{2+}$ fingers whose structure is highly organized upon $\mathrm{Zn}^{2+}$ complexation [80]. C2H2 type with two Cysteines (Cys or C) followed by a pair of Histidines (His or $\mathrm{H}$ ) is one of the most ubiquitous coordination sites for $\mathrm{Zn}^{2+}$ (Figure 6A). This configuration has been recognized within the C-terminal tail of the RYR2 channel [55] and the inositol-1,4,5-trisphosphate receptor isoform-1 (IP $\left.{ }_{3} \mathrm{R} 1\right)$ [81,82]. The $\mathrm{IP}_{3} \mathrm{R} 1$ channel participates in $\mathrm{Ca}^{2+}$ transport across the ER membrane in all cell types (reviewed in [83]). The classical $\mathrm{C} 2 \mathrm{H} 2$ topology has the consensus sequence $\mathrm{C}-\mathrm{X}_{2-5}-\mathrm{C}-\mathrm{X}_{12}-\mathrm{H}-\mathrm{X}_{3-4}-\mathrm{H}(\mathrm{X}$ is for any amino acid) (reviewed in [84]). To determine and compare spacing in the $\mathrm{C} 2 \mathrm{H} 2$ $\mathrm{Zn}^{2+}$ fingers of RYR2 and $\mathrm{IP}_{3} \mathrm{R} 1$ channels, we computed the alignment of their C-terminal sequences using the ClustalX method (Figure 6B; [85]). Instead of focusing on rat channels, we extended our analysis to other mammalians such as mouse, dog and human, which are commonly used as a source of RYR2 and $\mathrm{IP}_{3} \mathrm{R} 1$ channels for BLM experiments. Within this set, the first Cys and the second Cys are separated by two residues and this spacing is well conserved across mammalian RYR2 and $\mathrm{IP}_{3} \mathrm{R} 1$ channels. Further, the interhistidine spacing of four residues is conserved as well. Up to here, the topology of RYR2 and $\mathrm{IP}_{3} \mathrm{R} 1$ $\mathrm{Zn}^{2+}$ fingers matches the classical $\mathrm{C} 2 \mathrm{H} 2$ pattern. However, we revealed one deviation in the distance between Cys-Cys and His-His pairs. The spacing of 16 residues is uncommon (Figure 6B). According to the consensus sequence, 12 residues are allowed, albeit, it has been shown that 10-14 residues could also be tolerated (atypical C2H2, Figure 6A). In the RYR2 sequence, specifically, we located one additional conserved His that is 11 residues away from the Cys-Cys pair and four residues from the following His. It is thus conceivable that this newly-identified His residue could act as the third $\mathrm{Zn}^{2+}$ ligand matching the overall spacing of the atypical $\mathrm{C} 2 \mathrm{H} 2$ topology. 
A

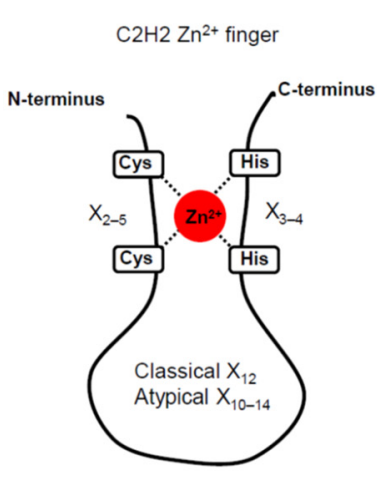

B

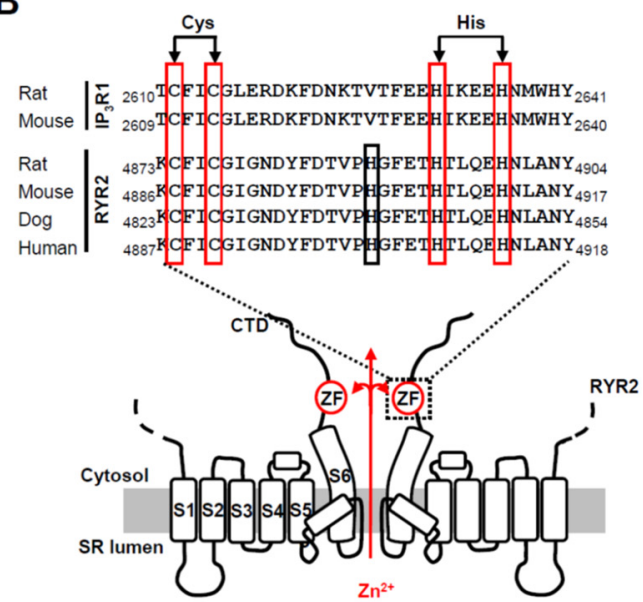

D

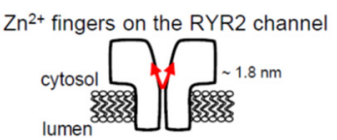

Neighboring RYR2 channels

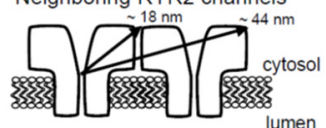

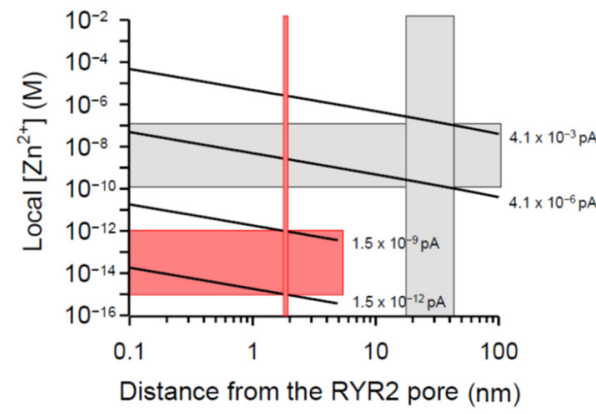

Figure 6. The RYR2 $\mathrm{Zn}^{2+}$ finger might be locally controlled by the $\mathrm{Zn}^{2+}$ current. (A) A schematic representation of the $\mathrm{C} 2 \mathrm{H} 2 \mathrm{Zn}^{2+}$ finger consisting of two Cysteines (Cys or $\mathrm{C}$ ) and two Histidines (His or $\mathrm{H}$ ), which are coordinated by $\mathrm{Zn}^{2+}$ cation. Usually, 12 residues separate the last $\mathrm{Cys}$ and the first His residues (classical $\mathrm{C} 2 \mathrm{H} 2$ pattern). In atypical $\mathrm{C} 2 \mathrm{H} 2 \mathrm{Zn}^{2+}$ fingers which still retain the ability to bind $\mathrm{Zn}^{2+}, 10-14$ residues are tolerated. (B) Sequence alignment of the $\mathrm{Zn}^{2+}$ finger motifs identified within the C-terminal tail of the rat and mouse $\mathrm{IP}_{3} \mathrm{R} 1$ channels [81,82] and the RYR2 channel [55] from indicated mammals. The sequences were taken from the UniProtKB database. The Cys and His residues of the $\mathrm{Zn}^{2+}$ finger domains with uncommon spacing (16 residues separating the Cys-Cys pair from the His-His pair) are boxed in red. The conserved His in the RYR2 sequences located 11 residues from the Cys-Cys pair, but not in the $\mathrm{IP}_{3} \mathrm{R} 1$ sequence, is highlighted in black. The membrane topology model of two opposing RYR2 subunits with six transmembrane domains was generated from recent work on the near-atomic resolution structure of the RYR2 isoform [55]. The putative $\mathrm{Zn}^{2+}$-finger domains (ZF) within the C-terminal tails might be supplied with luminal $\mathrm{Zn}^{2+}$ emanating from the RYR2 pore in the lumen-to-cytosol direction when the channel is open. (C) The theoretical prediction of local $\mathrm{Zn}^{2+}$ in respect to a distance from the $\mathrm{Zn}^{2+}$ exit site (the open RYR2 pore). $\mathrm{Zn}^{2+}$ accumulation profile was calculated with buffer present $\left(1 \mathrm{mM}\right.$ EGTA). The red vertical bar indicates the $\mathrm{Zn}^{2+}$ finger distance from a $\mathrm{Zn}^{2+}$ point source $(\sim 1.8 \mathrm{~nm})$. The gray vertical box indicates the center-to-corner distances covering the cytosolic domain of the neighboring RYR2 channel $(\sim 18-44 \mathrm{~nm})$. At a distance of $\sim 1.8 \mathrm{~nm}$, the $\mathrm{I}_{0, \mathrm{Zn}}$ of $1.5 \times 10^{-12}-1.5 \times 10^{-9} \mathrm{pA}$ is required to elevate $\left[\mathrm{Zn}^{2+}\right]$ up to the femtomolar range (horizontal red bar), sufficient to saturate the $\mathrm{Zn}^{2+}$ fingers. At a distance of $\sim 18-44 \mathrm{~nm}$, the $\mathrm{I}_{0, Z n}$ of $4.1 \times 10^{-6}-4.1 \times 10^{-3} \mathrm{pA}$ is required to reach activating $\left[\mathrm{Zn}^{2+}\right]$ from $100 \mathrm{pM}$ to $100 \mathrm{nM}$ (horizontal gray bar). (D) Schematic depicting distances of the RYR2 $\mathrm{Zn}^{2+}$ fingers and cytosolic domain of the neighboring RYR2 channel from the $\mathrm{Zn}^{2+}$ exit site to help place the values on the $\mathrm{X}$ axis, shown in (C), in context.

Despite a little doubt about the composition of the RYR2 $\mathrm{Zn}^{2+}$ finger, its location at the joint between the CTD (C-terminal domain) and the last transmembrane segment (S6) remains indisputable [55]. Since the $\mathrm{Zn}^{2+}$ finger domain is oriented toward the channel 
permeation pathway it is feasible to test the possibility that this domain is directly targeted by the $\mathrm{Zn}^{2+}$ current (Figure $6 \mathrm{~B}$ ). We began by calculating the free $\left[\mathrm{Zn}^{2+}\right]$ profile around an open RYR2 pore. Considering the extremely high binding affinities of numerous $\mathrm{Zn}^{2+}$ fingers in the femtomolar range [86-88], Figure 6C shows that an extremely small $\mathrm{Zn}^{2+}$ current (from $1.5 \times 10^{-12} \mathrm{pA}$ to $1.5 \times 10^{-9} \mathrm{pA}$ ) would be sufficient to achieve femtomolar $\left[\mathrm{Zn}^{2+}\right]$ around the $\mathrm{Zn}^{2+}$ finger located $\sim 1.8 \mathrm{~nm}$ from the channel pore (Figure 6D, top panel; [55]). Since the RYR2 channel has been shown to be sensitive to cytosolic $\mathrm{Zn}^{2+}[89,90]$ and the channel itself seems to be resistant to its own current [91], we extended our calculations also to the neighboring RYR2 channels that might be targeted via $\mathrm{Zn}^{2+}$ diffusion. This scenario should also receive attention because in the heart, RYR2 channels operate in small packed clusters [92,93] and at the single channel level, two or more RYR2 channels can be occasionally reconstituted, perhaps at their normal cellular spacing. Recent BLM studies have presented evidence that $\mathrm{Ca}^{2+}$-activated RYR2 channels are substantially modulated by cytosolic $\mathrm{Zn}^{2+}$ (100 pM-100 nM) [89,90]. To reach this magnitude change over the entire cytosolic domain of the neighboring channel, where $\mathrm{Zn}^{2+}$ binding sites must be located, the $\mathrm{I}_{0, \mathrm{Zn}}$ from $4.1 \times 10^{-6} \mathrm{pA}$ to $4.1 \times 10^{-3} \mathrm{pA}$ is required (Figure $6 \mathrm{C}$ ). Center-to-corner distances of $\sim 18 \mathrm{~nm}$ and $\sim 44 \mathrm{~nm}$ were taken from Liu et al. [91] and are indicated in Figure 6D (bottom panel). Such $\mathrm{I}_{0, \mathrm{Zn}}$ values are 122- to 122,000 -fold lower in comparison to the physiologically relevant amplitude of the $\mathrm{Ca}^{2+}$ current $(\sim 0.5 \mathrm{pA})$ flowing through the RYR2 channel $[77,78]$. Thus, our calculations suggest that RYR2 function might be significantly affected by almost negligible $\mathrm{Zn}^{2+}$ current of more than or equal to $4.1 \times 10^{-6} \mathrm{pA}$, which could be reachable in cardiomyocytes.

\subsection{Displacement of $\mathrm{Zn}^{2+}$ from the $\mathrm{RYR} 2 \mathrm{Zn}^{2+}$ Finger}

To further test the idea that the $\mathrm{Zn}^{2+}$ current supplies $\mathrm{Zn}^{2+}$ cations essential for the stabilization of the RYR2 $\mathrm{Zn}^{2+}$ finger, we assessed the accessibility of this $\mathrm{Zn}^{2+}$ binding site from either channel side (cytosolic and luminal) by displaying $\mathrm{Zn}^{2+}$ from its structure. As a nondestructive readout for this event, we monitored RYR2 $P_{O}$ because it has been evidenced that the $\mathrm{Zn}^{2+}$ finger is fundamental to the channel activation by caffeine [55]. First, we tested whether $\mathrm{Zn}^{2+}$ chelating agents such as NTA or TPEN could compete for $\mathrm{Zn}^{2+}$ when applied to the RYR2 cytosolic side. Based on the purity assays of ultrapure chemicals (SigmaAldrich) and the strong binding affinity of EGTA to $\mathrm{Zn}^{2+}$, we estimated that $\sim 2.13 \mathrm{pM}$ $\left[\mathrm{Zn}^{2+}\right]_{C}$ should have always been present in the cytosolic solution. When $5 \mathrm{mM}$ NTA was added, $\left[\mathrm{Zn}^{2+}\right]_{\mathrm{C}}$ dropped down to $0.5 \mathrm{pM}$. During 20-min incubation, the RYR2 Po did not change significantly (Figure 7A, left panel). Although, $5 \mu \mathrm{M}$ TPEN decreased free $\left[\mathrm{Zn}^{2+}\right]_{C}$ to the attomolar range $(7.2 \mathrm{aM}=0.0072 \mathrm{fM})$, no significant change in the channel activity was observed during 20-min exposure (Figure 7A, right panel). Insufficiently high $\mathrm{Zn}^{2+}$ affinities of NTA and TPEN appear to be unlikely because binding affinities of numerous $\mathrm{Zn}^{2+}$ fingers are in the femtomolar range [86-88]. Presumably, a substantially longer incubation (it could reach hours) was needed to remove obviously tightly bound $\mathrm{Zn}^{2+}$ in the RYR2 $\mathrm{Zn}^{2+}$ finger, which could also be less approachable sitting deep in the RYR2 cytosolic vestibule. A short BLM lifetime, however, limited such demanding conditions. In a further attempt to displace $\mathrm{Zn}^{2+}$, we assessed whether a well-known competition between $\mathrm{Zn}^{2+}$ and $\mathrm{Cd}^{2+}$ in different eukaryotic $\mathrm{Zn}^{2+}$ fingers [94-97] could be a more direct approach. Given the comparable physical properties of $\mathrm{Cd}^{2+}$ with those of permeant $\mathrm{Ca}^{2+}$ and $\mathrm{Mg}^{2+}$ (Table 2), $\mathrm{Cd}^{2+}$ passage through the RYR2 channel might be expected. Indeed, we found that the luminal addition of $8 \mathrm{mM}\left[\mathrm{Cd}^{2+}\right]_{\mathrm{L}}$ to $8 \mathrm{mM}\left[\mathrm{Ca}^{2+}\right]_{\mathrm{L}}$ significantly decreased the RYR2 G, thus reflecting $\mathrm{Cd}^{2+}$ permeation (Figure $7 \mathrm{~B}$ ), as we evidenced for $\mathrm{Zn}^{2+}$ under the same conditions (Figure 5). This finding was crucial because it allowed us to approach the $\mathrm{Zn}^{2+}$ finger from the RYR2 luminal side by the $\mathrm{Cd}^{2+}$ current in the lumen-to-cytosol direction. Importantly, a drop in $\mathrm{pH}$ from $7.350 \pm 0.010$ to $7.234 \pm 0.016$ when $8 \mathrm{mM}$ $\left[\mathrm{Cd}^{2+}\right]_{\mathrm{L}}$ was added did not contribute to a decrease in $\mathrm{G}$ because a much larger $\mathrm{pH}$ change from 7.35 to 6.83 was essentially without effect (Figure 4B). In Figure 7C (top trace), the $\mathrm{Ca}^{2+}$ current was only passing the caffeine-activated RYR2 channel in the presence of $8 \mathrm{mM}$ 
$\left[\mathrm{Ca}^{2+}\right]_{\mathrm{L}}$. After the addition of $8 \mathrm{mM}\left[\mathrm{Cd}^{2+}\right]_{\mathrm{L}}$, a sudden decay of channel activity occurred after 8-min incubation and persisted within $20 \mathrm{~min}$ of exposure (Figure $7 \mathrm{C}$, bottom two traces). Figure 7D shows that the latency of RYR2 activity decay varied considerably with $\left[\mathrm{Cd}^{2+}\right]_{\mathrm{L}}$. As $\left[\mathrm{Cd}^{2+}\right]_{\mathrm{L}}$ increased from $8 \mathrm{mM}$ to $16 \mathrm{mM}$, the channel activity was suppressed within a shorter time due to a greater ability of $\mathrm{Cd}^{2+}$ to substitute for $\mathrm{Zn}^{2+}$. Importantly, RYR2 activity was not recovered when caffeine concentration was substantially increased to 6-7 mM. This indicates that RYR2 sensitivity to caffeine was not attenuated as a result of $\mathrm{Cd}^{2+} / \mathrm{Ca}^{2+}$ competition directly at the RYR2 luminal side, as previously shown for $\mathrm{Sr}^{2+}, \mathrm{Mg}^{2+}$, or $\mathrm{Ba}^{2+}$ (when competing with $1 \mathrm{mM}$ luminal $\mathrm{Ca}^{2+}$ ) [51]. Rather, the $\mathrm{Cd}^{2+}$ current destabilized the $\mathrm{Zn}^{2+}$ finger by replacing $\mathrm{Zn}^{2+}$ and thus promoting the decay of channel activity.

A
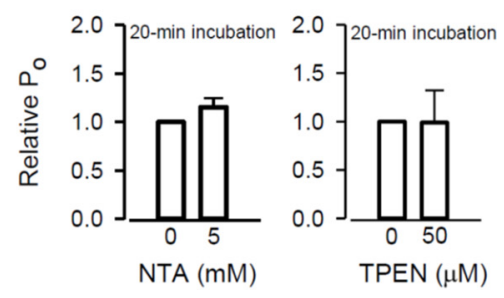

C

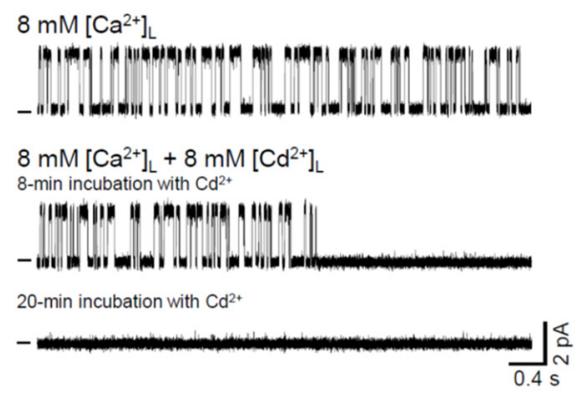

B

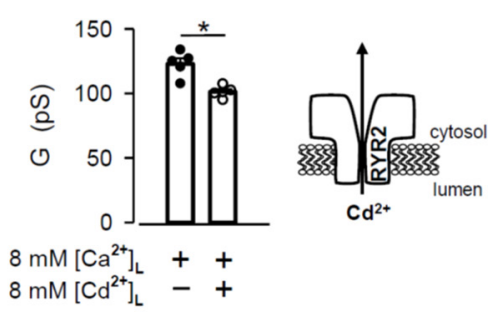

D

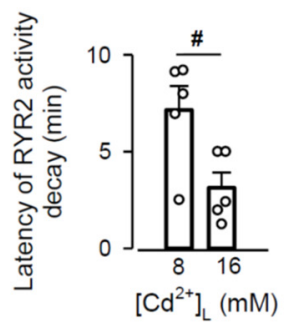

Figure 7. $\mathrm{Zn}^{2+}$ displacement from the RYR2 $\mathrm{Zn}^{2+}$ finger. (A) Effects of NTA (left panel) and TPEN (right panel) added to the cytosolic solution on RYR2 $\mathrm{P}_{\mathrm{O}}$ as a consequence of a decrease in $\left[\mathrm{Zn}^{2+}\right]_{\mathrm{C}}$ (paired Student's $t$ test). (B) The effect of $\mathrm{Cd}^{2+}$ addition $(8 \mathrm{mM})$ on the RYR2 $\mathrm{G}$ under near-saturating conditions when $8 \mathrm{mM}\left[\mathrm{Ca}^{2+}\right]_{\mathrm{L}}$ was present. * Significantly different from the control values when only luminal $\mathrm{Ca}^{2+}$ was present (paired Student's $t$ test). (C) Representative RYR2 currents, shown as

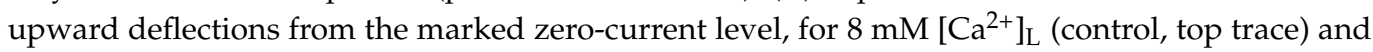
when $8 \mathrm{mM}\left[\mathrm{Cd}^{2+}\right]_{\mathrm{L}}$ was added (two bottom traces). RYR2 channels were activated by $1-2 \mathrm{mM}$ caffeine in the presence of $90 \mathrm{nM}$ free $\left[\mathrm{Ca}^{2+}\right]_{\mathrm{C}}$. Current recordings were conducted at $0 \mathrm{mV}$ and are from the same channel. (D) Latency of RYR2 activity decay as a function of $\left[\mathrm{Cd}^{2+}\right]_{\mathrm{L}} \cdot{ }^{*}$ Significantly different from $8 \mathrm{mM}\left[\mathrm{Cd}^{2+}\right]_{\mathrm{L}}$ (unpaired Student's $t$ test). Data shown are average $\pm \mathrm{SEM}$ of 5-7 experiments. Data points shown in (B) and (D) are individual measurements $\left(\mathrm{Ca}^{2+}\right.$-black circle and $\mathrm{Cd}^{2+} / \mathrm{Ca}^{2+}$-white circle).

\section{Discussion}

There has been a rapidly growing interest in the field of $\mathrm{Zn}^{2+}$ biology in the last ten years because of significant advances in the knowledge of $\mathrm{Zn}^{2+}$ chemistry and biochemistry. Moreover, defective $\mathrm{Zn}^{2+}$ cellular homeostasis has been implicated in the pathophysiology of cancer and diabetes, common diseases which greatly affect global health. This has further stimulated an intensive research effort to understand the importance of $\mathrm{Zn}^{2+}$ in a diverse spectrum of biological functions. In mammalian cells, large amounts of $\mathrm{Zn}^{2+}$ accumulate in various cellular compartments and organelles [34-36], mainly as a structural or catalytic factor directly regulating a great number of protein functions. To be candidates for $\mathrm{Zn}^{2+}$ signaling, intracellular $\mathrm{Zn}^{2+}$ storages must have proteins for both $\mathrm{Zn}^{2+}$ release and reuptake. Although, $\mathrm{Zn}^{2+}$ transporters such as $\mathrm{ZIP}$ and $\mathrm{ZnT}$ with subcellular distribution 
have been identified in various mammalian cells (reviewed in [17-19]), a limited number of studies have been conducted in cardiomyocytes. However, at least one member of the ZIP family responsible for $\mathrm{Zn}^{2+}$ release to the cytoplasm and one member of the $\mathrm{ZnT}$ family mediating $\mathrm{Zn}^{2+}$ transport in the opposite direction have been found [27,40] and localized to the cardiac SR membrane [41]. Although, these transporters assumingly participated in $\mathrm{Zn}^{2+}$ signaling originating from the SR [8,38], we put forward the possibility that the cardiac ryanodine receptor (RYR2) located in the SR membrane also contributes. It has been known for many years that the RYR2 channel is responsible for a massive release of $\mathrm{Ca}^{2+}$ from the SR required for muscle contraction (reviewed in [98]). Its role in $\mathrm{Zn}^{2+}$ signaling has however been overlooked. Tuncay et al. [8] revealed a significant suppression of $\mathrm{Zn}^{2+}$ transients by ryanodine in electrically stimulated cardiomyocytes. Ryanodine is a plant alkaloid that binds to all three isoforms of the RYR channel with high affinity and either holds the channel open in a state of reduced conductance or causes a complete inhibition, depending on its concentration [59,99-101]. According to Tuncay et al. [8], $\mathrm{Zn}^{2+}$ transients mostly resulted from an increase in $\left[\mathrm{Ca}^{2+}\right]_{\mathrm{C}}$ and subsequent $\mathrm{Zn}^{2+}$ displacement from intracellular binding sites. In such a scenario, $\mathrm{Zn}^{2+}$ transients would be suppressed in the presence of ryanodine, because $\mathrm{Ca}^{2+}$ release from the SR mediated by the RYR2 channel would be compromised. However, considering similar physical properties of $\mathrm{Zn}^{2+}$ with those of permeant $\mathrm{Mg}^{2+}$ (Table 2), the $\mathrm{Zn}^{2+}$ release through the RYR2 channel which would inevitably accompany $\mathrm{Ca}^{2+}$ release, could be an alternative explanation. Our study was therefore designed to investigate whether $\mathrm{Zn}^{2+}$ permeates the RYR2 channel reconstituted into the BLM.

\subsection{Permeation Properties of the RYR2 Channel for $\mathrm{Zn}^{2+}$}

In this study, the permeation properties of the rat RYR2 channel were examined under various ionic conditions. As shown in Figure 1, the $\mathrm{Zn}^{2+}$ currents through the RYR2 channel in the luminal-to-cytosol direction were recorded for the first time. Our results are compatible with several studies reporting a weak $\mathrm{Zn}^{2+}$ conductance for voltage-gated $\mathrm{Ca}^{2+}$ channels [102-105]. When $8 \mathrm{mM}\left[\mathrm{Zn}^{2+}\right]_{\mathrm{L}}$ was present and used as a sole charge carrier, the RYR2 $\mathrm{I}_{0, \mathrm{Zn}}$ was $0.927 \pm 0.093 \mathrm{pA}$. It is comparable to, but significantly smaller than, those obtained for luminal $\mathrm{Ca}^{2+}(2.835 \pm 0.094 \mathrm{pA})$ or even $\mathrm{Mg}^{2+}(1.822 \pm 0.079 \mathrm{pA})$ under similar conditions. Accordingly, the $\mathrm{G}$ values fall in the sequence $\mathrm{Ca}^{2+}(127.5 \pm 1.8 \mathrm{pS})$ $>\mathrm{Mg}^{2+}(95.3 \pm 1.4 \mathrm{pS})>\mathrm{Zn}^{2+}(81.1 \pm 2.4 \mathrm{pS})$. Such differences between $\mathrm{Zn}^{2+}$ and $\mathrm{Mg}^{2+}$ were unexpected as these cations have similar physical properties relevant to ion channel permeation (Table 2). To gain a better understanding, we evaluated the $\mathrm{Zn}^{2+}$ permeability coefficient relative to $\mathrm{Ca}^{2+}$. We performed mole-fraction experiments with a mixture of $\mathrm{Zn}^{2+}$ and $\mathrm{Ca}^{2+}$ on the luminal side (8 mM total concentration) and monitored the changes in RYR2 permeation properties. $\mathrm{Zn}^{2+}$ additions to the luminal solution resulted in specific changes when we used non-saturating concentrations of luminal $\mathrm{Ca}^{2+}$ in respect to the RYR2 conductance $(<8 \mathrm{mM})$. The $\mathrm{I}_{0}$ and $\mathrm{G}$ were increased while the $\mathrm{E}_{\text {rev }}$ was shifted towards more negative values (Figure 3 ). The changes were more pronounced in mixtures with the highest mole fractions of $\mathrm{Zn}^{2+}$. Under near-saturating conditions, where a competition between $\mathrm{Zn}^{2+}$ and $\mathrm{Ca}^{2+}$ could occur within the RYR2 permeation pathway [79], the $\mathrm{I}_{0}$ and $G$ were significantly decreased, but no change was revealed for $E_{\text {rev }}$ when $8 \mathrm{mM}\left[\mathrm{Zn}^{2+}\right]_{\mathrm{L}}$ was added to $8 \mathrm{mM}\left[\mathrm{Ca}^{2+}\right]_{\mathrm{L}}$ (Figure 5). Since the $\mathrm{I}_{0}$ and $\mathrm{G}$ did not drop below the values obtained for pure luminal $\mathrm{Zn}^{2+}$, this phenomenon cannot be interpreted as the anomalous mole fraction effect occurring when the values of $\mathrm{I}_{0}$ or $\mathrm{G}$ are lower in a mixture of two ions than in the pure solutions of individual ions at the same total concentration. To make such conclusion, we assumed that the permeation properties of the RYR 2 channel at $8 \mathrm{mM}$ and $16 \mathrm{mM}\left[\mathrm{Zn}^{2+}\right]_{\mathrm{L}}$ (the latter is not reachable at $\mathrm{pH} \sim 7.00$ ) are similar. This was not an unreasonable proposal, as $8 \mathrm{mM}$ concentration of divalent cations was found to be near-saturating.

In comparison to permeant $\mathrm{Mg}^{2+}, \mathrm{Zn}^{2+}$ displayed much less ability to contribute to permeation properties. The permeability coefficient for $\mathrm{Zn}^{2+}\left(\mathrm{P}_{\mathrm{Ca}} / \mathrm{P}_{\mathrm{Zn}}=2.65 \pm 0.19\right)$, esti- 
mated by fitting dependence of $\mathrm{E}_{\mathrm{rev}}$ on a composition of $\mathrm{Zn}^{2+} / \mathrm{Ca}^{2+}$ mixture by Equation (1), was found to be $\sim 2.3$-fold lower than that of $\mathrm{Mg}^{2+}\left(\mathrm{P}_{\mathrm{Ca}} / \mathrm{P}_{\mathrm{Mg}}=1.146 \pm 0.071\right)$. Because the permeability coefficient has been shown to be a diffusion component of channel selectivity and reflects how well particular ions pass through the channel pore [106], our results clearly indicate that the RYR2 channel can differentiate, albeit only moderately, between $\mathrm{Zn}^{2+}$ and $\mathrm{Mg}^{2+}$ or $\mathrm{Ca}^{2+}$, providing a slower path to $\mathrm{Zn}^{2+}$. In respect to $\mathrm{G}$, it has been proven that this parameter contains information not only about ion movement throughout the channel pore, but it also measures how well particular ions enter and exit the channel $[62,106]$. Since $\mathrm{Zn}^{2+}$ and $\mathrm{Mg}^{2+}$ exhibit a similar hydration enthalpy (Table 2), critically implicated in ion entry into the narrowest region of the channel pore [52,62], and as $\mathrm{Zn}^{2+}$ moves through the RYR2 channel more slowly than $\mathrm{Mg}^{2+}$, a lower $\mathrm{G}_{\mathrm{Zn}}$ is an inevitable consequence.

\subsection{Physiological Implications}

Ion channels are predominantly involved in rapid signal transduction because ion movement through ion channels is usually much faster than passive transport down the electrochemical gradient mediated by carrier-type transporters [107]. During each heartbeat, RYR2 channels are responsible for the release of a huge amount of $\mathrm{Ca}^{2+}$ from the SR lumen. Our study shows that the same route is also suitable for $\mathrm{Zn}^{2+}$ mobilization from the $\mathrm{SR}$, and thus $\mathrm{Zn}^{2+}$ might contribute to the RYR2 current of $\sim 0.5 \mathrm{pA}[77,78]$ during cardiac excitation-contraction coupling, albeit primarily driven by a 10,000 -fold $\mathrm{Ca}^{2+}$ gradient across the SR membrane (100 nM in the cytosol, $1 \mathrm{mM}$ in the SR lumen [108,109]). This seems reasonable, if we consider the extremely low free $\mathrm{Zn}^{2+}$ level of $\sim 100 \mathrm{pM}$ in the cytosol of cardiomyocytes $[3,110]$ and more than 60 -fold higher free $\left[\mathrm{Zn}^{2+}\right]$ in the cardiac SR lumen (>6 nM, [110]). The existence of a $\mathrm{Zn}^{2+}$ gradient, albeit $\sim 166$-fold smaller than for $\mathrm{Ca}^{2+}$, together with a considerable RYR2 permeability for $\mathrm{Zn}^{2+}$, is compatible with the biological significance of the $\mathrm{Zn}^{2+}$ current through the RYR2 channel. At the cellular level, Tuncay et al. [8] support this idea by visualizing ryanodine-sensitive $\mathrm{Zn}^{2+}$ transients in cardiomyocytes having similar kinetics to those of $\mathrm{Ca}^{2+}$. Furthermore, both $\mathrm{Ca}^{2+}$ and $\mathrm{Zn}^{2+}$ transients required a small $\mathrm{Ca}^{2+}$ influx from the extracellular space through the L-type $\mathrm{Ca}^{2+}$ channel in the plasma membrane. Thus, it seems reasonable to propose that the RYR2 channel has a real $\mathrm{Zn}^{2+}$ transport function in cardiomyocytes (Figure 8), but the cellular target for this $\mathrm{Zn}^{2+}$ release has not been established. Certainly, the release does not trigger contraction because $\mathrm{Zn}^{2+}$ only negligibly interacts with proteins of the contractile machinery [111]. However, $100 \mathrm{pM}-100 \mathrm{nM} \mathrm{Zn}^{2+}$ has been shown to shape $\mathrm{Ca}^{2+}$ release by amplifying the $\mathrm{Ca}^{2+}$-induced RYR2 activity $[89,90]$. According to our simple calculations, the $\mathrm{Zn}^{2+}$ current of more than or equal to $4.1 \times 10^{-6} \mathrm{pA}(\sim 0.0008 \%$ of the RYR2 current in cardiomyocytes) should be sufficient for the building up of activating $\left[\mathrm{Zn}^{2+}\right]$ near neighboring RYR2 channels (Figure 6C). This estimation suggests that almost negligible $\mathrm{Zn}^{2+}$ current mediated by one RYR2 channel could amplify $\mathrm{Ca}^{2+}$ release through neighboring RYR2 channels. This regulatory process might be impaired in cardiovascular diseases, which are often associated with $\mathrm{Zn}^{2+}$ deficiency [39,112-114]. It may arise from low intake, malabsorptive syndromes, or the administration of various medications (reviewed in [115]). In $\mathrm{Zn}^{2+}$-deficient cardiomyocytes, intracellular $\mathrm{Zn}^{2+}$ stores including the SR have been indeed found to be substantially depleted of $\mathrm{Zn}^{2+}$ [116]. One would then expect that the $\mathrm{Zn}^{2+}$ gradient across the SR membrane will be reduced, resulting in a compromised $\mathrm{Zn}^{2+}$ release. This implies that appropriate $\mathrm{Zn}^{2+}$ supplementation might be beneficial in the management of cardiovascular diseases, directly affecting $\mathrm{Ca}^{2+}$ signaling fundamental to the cardiac contraction. So far, a few studies have reported an improvement in symptoms of heart failure with $\mathrm{Zn}^{2+}$ supplementation [116-118]. Some clues on the physiological relevance of the RYR2 $\mathrm{Zn}^{2+}$ current, can also be found in work of Atar et al. [104], where changes in free $\left[\mathrm{Zn}^{2+}\right]_{C}$ have been linked to the activation of transcription in electrically stimulated cardiomyocytes, given the catalytic and structural roles of $\mathrm{Zn}^{2+}$ in DNA- and RNA-binding proteins. 

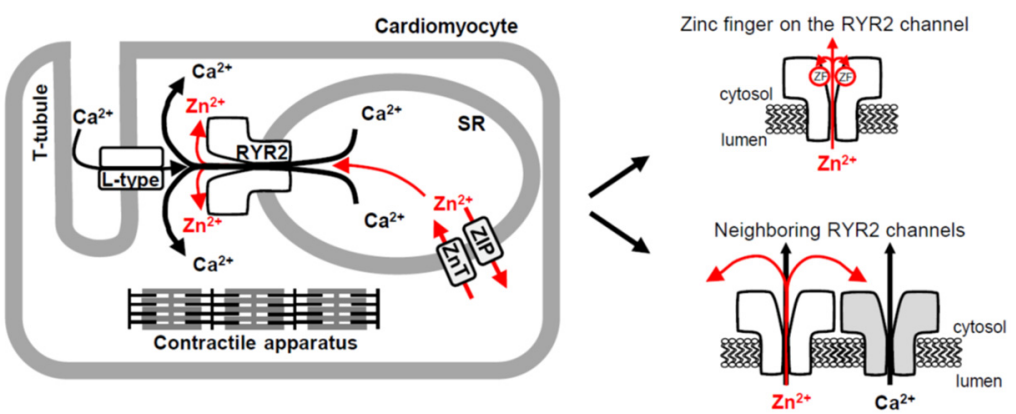

Figure 8. The RYR2 channel provides a novel pathway for rapid $\mathrm{Zn}^{2+}$ transport in cardiomyocytes. Schematic illustrating three pathways (one novel) for $\mathrm{Zn}^{2+}$ transport across the cardiac SR membrane. Two $\mathrm{Zn}^{2+}$ transporter protein families, ZIP and $\mathrm{ZnT}$, play an essential role in cardiac $\mathrm{Zn}^{2+}$ homeostasis and mediate a slow-rate transport. In the heart, $\mathrm{Zn}^{2+}$ release through the RYR2 channel, accompanying a robust $\mathrm{Ca}^{2+}$ release triggered by small $\mathrm{Ca}^{2+}$ entry through the L-type $\mathrm{Ca}^{2+}$ channel, could also contribute to global and/or local $\mathrm{Zn}^{2+}$ signaling which requires a fast-rate transport. At the local scale, the $\mathrm{Zn}^{2+}$ current flowing through the RYR2 channel might target its intrinsic $\mathrm{Zn}^{2+}$ finger situated within the C-terminal tail of all four RYR2 subunits. In addition, the RYR2 channel (colored gray) might be stimulated by $\mathrm{Zn}^{2+}$ cations emanating from the neighboring RYR2 channel (colored white). Arrows indicate the direction of $\mathrm{Zn}^{2+}$ (red) and $\mathrm{Ca}^{2+}$ (black) mobilization.

Numerous proteins with a variety of functions, including transcription, protein degradation, and DNA repair harbor small structured domains, the $\mathrm{Zn}^{2+}$ fingers, whose stability is dramatically improved by $\mathrm{Zn}^{2+}$ binding. The $\mathrm{C} 2 \mathrm{H} 2 \mathrm{Zn}^{2+}$ finger with two Cys (C) followed by a pair of His residues $(\mathrm{H})$ (Figure $6 \mathrm{~A}$ ) has also been identified within the $\mathrm{C}$-terminal tail of structurally related $\mathrm{IP}_{3} \mathrm{R} 1$ [81,82] and RYR2 channels [55] (Figure 6B). When individual or combined Cys and His residues were mutated, $\mathrm{IP}_{3} \mathrm{R} 1$ function was completely abolished highlighting the critical role of the C-terminus in channel gating $[81,82]$. The C-terminal region is highly conserved in both the $\mathrm{IP}_{3} \mathrm{R}$ and $\mathrm{RYR}$ families [119] and therefore it is not surprising that similar results were obtained for the RYR2 channel. The channel completely lost its ability to gate when both Cys residues and only the first of a His-His pair were individually substituted [55]. Surprisingly, mutation of the final His residue caused no change and the RYR2 channel retained its function. This is in sharp contrast to the $\mathrm{IP}_{3} \mathrm{R} 1$ channel, where a critical importance of the final His residue in the $\mathrm{Zn}^{2+}$ finger sequence has been reported [82], albeit the spacing between the Cys-Cys and His-His pairs is uncommon (16 instead of classical 12 or atypical 10-14 residues, Figure 6B). The same deviation has also been demonstrated for the RYR2 channel [55], although we found one nearer conserved His, 11 residues away from the Cys-Cys pair (atypical C2H2 pattern), that could potentially serve as a third $\mathrm{Zn}^{2+}$ ligand when pairing with the following His (Figure 6B). To address such uncertainty in the composition of RYR2 $\mathrm{Zn}^{2+}$ finger, the mutation of the newly-identified His residue should be studied in the context of RYR2 function and $\mathrm{Zn}^{2+}$ binding properties.

The $\mathrm{Zn}^{2+}$ finger domain of each of the four RYR2 subunits impinges toward the central vertical axis of the channel permeation pathway, thus it may be well supplied with the $\mathrm{Zn}^{2+}$ current to ensure a proper channel function (Figure 8). In agreement with this prediction, the $\mathrm{Cd}^{2+}$ current passing the RYR2 channel in the lumen-to-cytosol direction caused a sudden decay of RYR2 activity. Since this action was specific for $\mathrm{Cd}^{2+}$ because the luminal additions of other divalent cations never had such detrimental effects [50,51], it was highly likely due to $\mathrm{Zn}^{2+}$ to $\mathrm{Cd}^{2+}$ replacement in the RYR2 $\mathrm{Zn}^{2+}$ finger. Obviously, $\mathrm{Zn}^{2+}$ displacement by $\mathrm{Cd}^{2+}$ was not structurally tolerated, and therefore RYR2 function was abolished. If the RYR2 $\mathrm{Zn}^{2+}$ current was fundamental to stabilization of the $\mathrm{Zn}^{2+}$ finger structure, one could ask why the channel function was not impaired in the absence of luminal $\mathrm{Zn}^{2+}$ when only $\mathrm{Ca}^{2+}$ or $\mathrm{Mg}^{2+}$ currents were carried by the channel. The answer could be found in $\mathrm{Zn}^{2+}$ impurities coming from otherwise ultrapure chemicals. We estimated that $\sim 2.13 \mathrm{pM}$ and $\sim 0.8-1.0 \mathrm{nM}$ free $\left[\mathrm{Zn}^{2+}\right]$ was present in the cytosolic and 
luminal solutions, respectively. In generally, eukaryotic $\mathrm{Zn}^{2+}$ fingers possess the extremely high binding affinities in the femtomolar range [86-88], therefore, picomolar $\left[\mathrm{Zn}^{2+}\right]$ on the RYR2 cytosolic side should have been sufficient to saturate the $\mathrm{Zn}^{2+}$ finger, albeit the deep position of this $\mathrm{Zn}^{2+}$-stabilized domain within the cytosolic portion of the RYR2 permeation pathway could considerably impair this process. We tested this idea by adding strong $\mathrm{Zn}^{2+}$ chelators such as NTA and TPEN to reach the atto-femtomolar free $\left[\mathrm{Zn}^{2+}\right]_{C}$, and thus facilitate $\mathrm{Zn}^{2+}$ displacement from the channel. This strategy was, however, not successful. One reason was probably the specific binding properties of the RYR2 $\mathrm{Zn}^{2+}$ finger. It is reasonable to assume that $\mathrm{Zn}^{2+}$ has to be tightly bound even under conditions of a transient depletion in $\mathrm{Zn}^{2+}$ because the RYR2 channel plays a dominant role in cardiac excitation-contraction coupling [42-44], and thus a proper RYR2 function is of particular importance. On the other hand, the $\sim 470$-fold $\mathrm{Zn}^{2+}$ gradient across the BLM, which was always present due to $\mathrm{Zn}^{2+}$ impurities, also likely contributed. Our calculations suggest that almost negligible $\mathrm{Zn}^{2+}$ current $\left(\geq 1.5 \times 10^{-12} \mathrm{pA}\right)$ is required to accumulate femtomolar $\left[\mathrm{Zn}^{2+}\right]$ near the $\mathrm{Zn}^{2+}$ finger position $(\sim 1.8 \mathrm{~nm}$ from the pore). In cardiomyocytes, this extremely small current is seemingly also reachable, albeit $\mathrm{Zn}^{2+}$ movement will be driven by a smaller $\mathrm{Zn}^{2+}$ gradient compared to BLM experiments. Taken together, it appears that the RYR2 $\mathrm{Zn}^{2+}$ finger is more accessible from the luminal than the cytosolic side of the channel since $\mathrm{Cd}^{2+}$ current (from lumen to cytosol) replaced $\mathrm{Zn}^{2+}$ bound in the $\mathrm{Zn}^{2+}$ finger domain even in the presence of saturating $\left[\mathrm{Zn}^{2+}\right]_{C}$ in the cytosolic solution. In contrast, a substantial decrease in $\left[\mathrm{Zn}^{2+}\right]_{C}$ to the non-saturating range had no effect on $\mathrm{Zn}^{2+}-\mathrm{RYR} 2$ interactions when a subtle $\mathrm{Zn}^{2+}$ current in the lumen-to-cytosol direction occurred.

\section{Conclusions}

Here, we identify the RYR2 channel as a novel $\mathrm{Zn}^{2+}$ transporting protein in the SR membrane that might play a role in local and/or global $\mathrm{Zn}^{2+}$ signaling in cardiomyocytes, considering much faster ion movement through ion channels than the passive transport mediated by carrier-type transporters. The results demonstrate that the RYR2 channel itself could be regulated by its own $\mathrm{Zn}^{2+}$ current. Since $\mathrm{Zn}^{2+}$-binding domains, such as the $\mathrm{Zn}^{2+}$ fingers, often display extremely high binding affinities in the femtomolar range a subtle $\mathrm{Zn}^{2+}$ current in the lumen-to-cytosol direction was predicted to be sufficient for the saturation of the $\mathrm{Zn}^{2+}$ finger situated within the C-terminal tail of each of the four RYR2 subunits. It is not an unreasonable proposal, because the RYR2 $\mathrm{Zn}^{2+}$ finger is directed toward the permeation pathway, and thus it will inevitably be targeted by the $\mathrm{Zn}^{2+}$ current.

Author Contributions: Conceptualization, J.G. and M.G.; methodology, J.G. and M.G.; software, J.G.; validation, J.G. and M.G.; formal analysis, J.G. and M.G.; investigation, J.G. and M.G.; resources, J.G. and M.G.; data curation, J.G. and M.G.; writing-original draft preparation, J.G. and M.G.; writingreview and editing, M.G.; visualization, M.G.; project administration, J.G.; funding acquisition, J.G. and M.G. All authors have read and agreed to the published version of the manuscript.

Funding: This research was funded by the Grant Agency of the Ministry of Education, Science, Research and Sport of the Slovak Republic and the Slovak Academy of Sciences (grants VEGA 2/0018/21 and VEGA 2/0008/20) and the Research \& Development Operational Program (ITMS 26230120009) funded by the European Fund for Regional Development.

Institutional Review Board Statement: The animal study protocol was approved by the State Veterinary and Food Administration of the Slovak Republic (permit number: 2721/17-221 and 2100/19-221 approved 4 July 2017).

Informed Consent Statement: Not applicable.

Data Availability Statement: The datasets generated for this study are available on request to the corresponding authors.

Conflicts of Interest: The authors declare no conflict of interest. The funders had no role in the design of the study; in the collection, analyses, or interpretation of data; in the writing of the manuscript, or in the decision to publish the results. 


\section{References}

1. MacDonald, R.S. The role of zinc in growth and cell proliferation. J. Nutr. 2000, 130, 1500S-1508S. [CrossRef] [PubMed]

2. Maret, W. Zinc in cellular regulation: The nature and significance of “zinc signals". Int. J. Mol. Sci. 2017, 18, 2285. [CrossRef] [PubMed]

3. Turan, B.; Fliss, H.; Désilets, M. Oxidants increase intracellular free $\mathrm{Zn}^{2+}$ concentration in rabbit ventricular myocytes. Am. J. Physiol. 1997, 272, H2095-H2106. [CrossRef] [PubMed]

4. Prasad, A.S. Impact of the discovery of human zinc deficiency on health. J. Am. Coll. Nutr. 2009, 28, 257-265. [CrossRef]

5. Prasad, A.S.; Beck, F.W.; Snell, D.C.; Kucuk, O. Zinc in cancer prevention. Nutr. Cancer 2009, 61, 879-887. [CrossRef]

6. Sensi, S.L.; Paoletti, P.; Bush, A.I.; Sekler, I. Zinc in the physiology and pathology of the CNS. Nat. Rev. Neurosci. 2009, 10, 780-791. [CrossRef]

7. Little, P.J.; Bhattacharya, R.; Moreyra, A.E.; Korichneva, I.L. Zinc and cardiovascular disease. Nutrition 2010, 26, 1050-1057. [CrossRef]

8. Tuncay, E.; Bilginoglu, A.; Sozmen, N.N.; Zeydanli, E.N.; Ugur, M.; Vassort, G.; Turan, B. Intracellular free zinc during cardiac excitation-contraction cycle: Calcium and redox dependencies. Cardiovasc. Res. 2011, 89, 634-642. [CrossRef]

9. Krizkova, S.; Ryvolova, M.; Hrabeta, J.; Adam, V.; Stiborova, M.; Eckschlager, T.; Kizek, R. Metallothioneins and zinc in cancer diagnosis and therapy. Drug Metab. Rev. 2012, 44, 287-301. [CrossRef]

10. Vallee, B.L.; Auld, D.S. Cocatalytic zinc motifs in enzyme catalysis. Proc. Natl. Acad. Sci. USA 1993, 90, 2715-2718. [CrossRef]

11. Prasad, A.S. Zinc: An overview. Nutrition 1995, 11, 93-99. [PubMed]

12. Peck, E.J., Jr.; Ray, W.J., Jr. Metal complexes of phosphoglucomutase in vivo. Alterations induced by insulin. J. Biol. Chem. 1971, 246, 1160-1167. [CrossRef]

13. Simons, T.J.B. Intracellular free zinc and zinc buffering in human red blood cells. J. Membr. Biol. 1991, 123, 63-71. [CrossRef] [PubMed]

14. Benters, J.; Flögel, U.; Schäfer, T.; Leibfritz, D.; Hechtenberg, S.; Beyersmann, D. Study of the interactions of cadmium and zinc ions with cellular calcium homoeostasis using 19F-NMR spectroscopy. Biochem. J. 1997, 322, 793-799. [CrossRef]

15. Bozym, R.A.; Thompson, R.B.; Stoddard, A.K.; Fierke, C.A. Measuring picomolar intracellular exchangeable zinc in PC-12 cells using a ratiometric fluorescence biosensor. ACS Chem. Biol. 2006, 1, 103-111. [CrossRef]

16. Colvin, R.A.; Holmes, W.R.; Fontaine, C.P.; Maret, W. Cytosolic zinc buffering and muffling: Their role in intracellular zinc homeostasis. Metallomics 2010, 2, 306-317. [CrossRef]

17. Lichten, L.A.; Cousins, R.J. Mammalian zinc transporters: Nutritional and physiologic regulation. Annu. Rev. Nutr. 2009, 29, 153-176. [CrossRef]

18. Kambe, T.; Tsuji, T.; Hashimoto, A.; Itsumura, N. The physiological, biochemical, and molecular roles of zinc transporters in zinc homeostasis and metabolism. Physiol. Rev. 2015, 95, 749-784. [CrossRef]

19. Hara, T.; Takeda, T.A.; Takagishi, T.; Fukue, K.; Kambe, T.; Fukada, T. Physiological roles of zinc transporters: Molecular and genetic importance in zinc homeostasis. J. Physiol. Sci. 2017, 67, 283-301. [CrossRef]

20. Palmiter, R.D.; Findley, S.D. Cloning and functional characterization of a mammalian zinc transporter that confers resistance to zinc. EMBO J. 1995, 14, 639-649. [CrossRef]

21. Bruinsma, J.J.; Jirakulaporn, T.; Muslin, A.J.; Kornfeld, K. Zinc ions and cation diffusion facilitator proteins regulate Ras-mediated signaling. Dev. Cell 2002, 2, 567-578. [CrossRef]

22. Jirakulaporn, T.; Muslin, A.J. Cation diffusion facilitator proteins modulate Raf-1 activity. J. Biol. Chem. 2004, 279 , $27807-27815$. [CrossRef] [PubMed]

23. Zhang, Y.; Bharadwaj, U.; Logsdon, C.D.; Chen, C.; Yao, Q.; Li, M. ZIP4 regulates pancreatic cancer cell growth by activating IL-6/STAT3 pathway through zinc finger transcription factor CREB. Clin. Cancer Res. 2010, 16, 1423-1430. [CrossRef] [PubMed]

24. Hojyo, S.; Fukada, T.; Shimoda, S.; Ohashi, W.; Bin, B.H.; Koseki, H.; Hirano, T. The zinc transporter SLC39A14/ZIP14 controls G-protein coupled receptor-mediated signaling required for systemic growth. PLoS ONE 2011, 6, e18059. [CrossRef] [PubMed]

25. Beker Aydemir, T.; Chang, S.M.; Guthrie, G.J.; Maki, A.B.; Ryu, M.S.; Karabiyik, A.; Cousins, R.J. Zinc transporter ZIP14 functions in hepatic zinc, iron and glucose homeostasis during the innate immune response (endotoxemia). PLoS ONE 2012,7 , e48679. [CrossRef]

26. Chowanadisai, W.; Graham, D.M.; Keen, C.L.; Rucker, R.B.; Messerli, M.A. Neurulation and neurite extension require the zinc transporter ZIP12 (slc39a12). Proc. Natl. Acad. Sci. USA 2013, 110, 9903-9908. [CrossRef]

27. Kirschke, C.P.; Huang, L. ZnT7, a novel mammalian zinc transporter, accumulates zinc in the Golgi apparatus. J. Biol. Chem. 2003, 278, 4096-4102. [CrossRef]

28. Chi, Z.H.; Wang, X.; Wang, Z.Y.; Gao, H.L.; Dahlstrom, A.; Huang, L. Zinc transporter 7 is located in the cis-Golgi apparatus of mouse choroid epithelial cells. Neuroreport 2006, 17, 1807-1811. [CrossRef]

29. Lazarczyk, M.; Pons, C.; Mendoza, J.A.; Cassonnet, P.; Jacob, Y.; Favre, M. Regulation of cellular zinc balance as a potential mechanism of EVER-mediated protection against pathogenesis by cutaneous oncogenic human papillomaviruses. $J$. Exp. Med. 2008, 205, 35-42. [CrossRef]

30. Fukada, T.; Civic, N.; Furuichi, T.; Shimoda, S.; Mishima, K.; Higashiyama, H.; Idaira, Y.; Asada, Y.; Kitamura, H.; Yamasaki, S.; et al. The zinc transporter SLC39A13/ZIP13 is required for connective tissue development; its involvement in BMP/TGF-beta signaling pathways. PLoS ONE 2008, 3, e3642. [CrossRef] 
31. Hogstrand, C.; Kille, P.; Nicholson, R.I.; Taylor, K.M. Zinc transporters and cancer: A potential role for ZIP7 as a hub for tyrosine kinase activation. Trends Mol. Med. 2009, 15, 101-111. [CrossRef] [PubMed]

32. Taylor, K.M.; Hiscox, S.; Nicholson, R.I.; Hogstrand, C.; Kille, P. Protein kinase CK2 triggers cytosolic zinc signaling pathways by phosphorylation of zinc channel ZIP7. Sci. Signal. 2012, 5, ra11. [CrossRef] [PubMed]

33. Taniguchi, M.; Fukunaka, A.; Hagihara, M.; Watanabe, K.; Kamino, S.; Kambe, T.; Enomoto, S.; Hiromura, M. Essential role of the zinc transporter ZIP9/SLC39A9 in regulating the activations of Akt and Erk in B-cell receptor signaling pathway in DT40 cells. PLoS ONE 2013, 8, e58022. [CrossRef] [PubMed]

34. Bonnemaison, M.L.; Duffy, M.E.; Mains, R.E.; Vogt, S.; Eipper, B.A.; Ralle, M. Copper, zinc and calcium: Imaging and quantification in anterior pituitary secretory granules. Metallomics 2016, 8, 1012-1022. [CrossRef]

35. Lu, Q.; Haragopal, H.; Slepchenko, K.G.; Stork, C.; Li, Y.V. Intracellular zinc distribution in mitochondria, ER and the Golgi apparatus. Int. J. Physiol. Pathophysiol. Pharmacol. 2016, 8, 35-43.

36. Qi, Z.; Shi, W.; Zhao, Y.; Ji, X.; Liu, K.J. Zinc accumulation in mitochondria promotes ischemia-induced BBB disruption through Drp1-dependent mitochondria fission. Toxicol. Appl. Pharmacol. 2019, 377, 114601. [CrossRef]

37. Stork, C.J.; Li, Y.V. Zinc release from thapsigargin/ $\mathrm{IP}_{3}$-sensitive stores in cultured cortical neurons. J. Mol. Signal. 2010,5 , 5. [CrossRef]

38. Palmer, B.M.; Vogt, S.; Chen, Z.Y.; Lachapelle, R.R.; LeWinter, M.M. Intracellular distributions of essential elements in cardiomyocytes. J. Struct. Biol. 2006, 155, 12-21. [CrossRef]

39. Etzion, Y.; Ganiel, A.; Beharier, O.; Shalev, A.; Novack, V.; Volvich, L.; Abrahamov, D.; Matsa, M.; Sahar, G.; Moran, A.; et al. Correlation between atrial ZnT-1 expression and atrial fibrillation in humans: A pilot study. J. Cardiovasc. Electrophysiol. 2008, 19, 157-164. [CrossRef]

40. Yang, J.; Zhang, Y.; Cui, X.; Yao, W.; Yu, X.; Cen, P.; Hodges, S.E.; Fisher, W.E.; Brunicardi, F.C.; Chen, C.; et al. Gene profile identifies Zinc transporters differentially expressed in normal human organs and human pancreatic cancer. Curr. Mol. Med. 2013, 13, 401-409.

41. Tuncay, E.; Bitirim, V.C.; Durak, A.; Carrat, G.R.J.; Taylor, K.M.; Rutter, G.A.; Turan, B. Hyperglycemia-induced changes in ZIP7 and $\mathrm{ZnT7}$ expression cause $\mathrm{Zn}^{2+}$ release from sarco(endo)plasmic reticulum and mediate ER-stress in the heart. Diabetes 2017, 66, 1346-1358. [CrossRef] [PubMed]

42. Endo, M.; Tanaka, M.; Ogawa, Y. Calcium induced release of calcium from the sarcoplasmic reticulum of skinned skeletal muscle fibres. Nature 1970, 228, 34-36. [CrossRef] [PubMed]

43. Fabiato, A. Calcium-induced release of calcium from the cardiac sarcoplasmic reticulum. Am. J. Physiol. 1983, 245, C1-C14. [CrossRef]

44. Fabiato, A. Simulated calcium current can both cause calcium loading in and trigger calcium release from the sarcoplasmic reticulum of a skinned canine cardiac Purkinje cell. J. Gen. Physiol. 1985, 85, 291-320. [CrossRef]

45. Lindsay, A.R.G.; Williams, A.J. Functional-characterization of the ryanodine receptor purified from sheep cardiac-muscle sarcoplasmic-reticulum. Biochim. Biophys. Acta 1991, 1064, 89-102. [CrossRef]

46. Tinker, A.; Williams, A.J. Divalent-cation conduction in the ryanodine receptor channel of sheep cardiac-muscle sarcoplasmicreticulum. J. Gen. Physiol. 1992, 100, 479-493. [CrossRef] [PubMed]

47. Hess, P.; Lansman, J.B.; Tsien, R.W. Calcium channel selectivity for divalent and monovalent cations. Voltage and concentration dependence of single channel current in ventricular heart cells. J. Gen. Physiol. 1986, 88, 293-319. [CrossRef]

48. Bezprozvanny, I.; Ehrlich, B.E. Inositol $(1,4,5)$-trisphosphate (InsP3)-gated $\mathrm{Ca}^{2+}$ channels from cerebellum: Conduction properties for divalent cations and regulation by intraluminal calcium. J. Gen. Physiol. 1994, 104, 821-856. [CrossRef]

49. Zoghbi, M.E.; Copello, J.A.; Villalba-Galea, C.A.; Vélez, P.; Diaz Sylvester, P.L.; Bolaños, P.; Marcano, A.; Fill, M.; Escobar, A.L. Differential $\mathrm{Ca}^{2+}$ and $\mathrm{Sr}^{2+}$ regulation of intracellular divalent cations release in ventricular myocytes. Cell Calcium 2004, 36, 119-134. [CrossRef]

50. Diaz-Sylvester, P.L.; Porta, M.; Copello, J.A. Modulation of cardiac ryanodine receptor channels by alkaline earth cations. PLoS ONE 2011, 6, e26693. [CrossRef]

51. Gaburjakova, J.; Gaburjakova, M. Cardiac ryanodine receptor: Selectivity for alkaline earth metal cations points to the EF-hand nature of luminal binding sites. Bioelectrochemistry 2016, 109, 49-56. [CrossRef] [PubMed]

52. Zhou, Y.; Morais-Cabral, J.H.; Kaufman, A.; Mackinnon, R. Chemistry of ion coordination and hydration revealed by a $\mathrm{K}^{+}$ channel-Fab complex at 2.0 Å resolution. Nature 2001, 414, 43-48. [CrossRef] [PubMed]

53. Gillespie, D. Energetics of divalent selectivity in a calcium channel: The ryanodine receptor case study. Biophys. J. 2008, 94, 1169-1184. [CrossRef] [PubMed]

54. Gillespie, D.; Xu, L.; Meissner, G. Selecting ions by size in a calcium channel: The ryanodine receptor case study. Biophys. J. 2014, 107, 2263-2273. [CrossRef]

55. Peng, W.; Shen, H.; Wu, J.; Guo, W.; Pan, X.; Wang, R.; Chen, S.R.W.; Yan, N. Structural basis for the gating mechanism of the type 2 ryanodine receptor RyR2. Science 2016, 354, aah5324. [CrossRef] [PubMed]

56. Rousseau, E.; Meissner, G. Single cardiac sarcoplasmic reticulum $\mathrm{Ca}^{2+}$-release channel: Activation by caffeine. Am. J. Physiol. 1989, 256, H328-H333. [CrossRef]

57. Sitsapesan, R.; Williams, A.J. Mechanisms of caffeine activation of single calcium-release channels of sheep cardiac sarcoplasmic reticulum. J. Physiol. 1990, 423, 425-439. [CrossRef] 
58. Porta, M.; Zima, A.V.; Nani, A.; Diaz-Sylvester, P.L.; Copello, J.A.; Ramos-Franco, J.; Blatter, L.A.; Fill, M. Single ryanodine receptor channel basis of caffeine's action on $\mathrm{Ca}^{2+}$ sparks. Biophys. J. 2011, 100, 931-938. [CrossRef]

59. Rousseau, E.; Smith, J.S.; Meissner, G. Ryanodine modifies conductance and gating behavior of single Ca ${ }^{2+}$ release channel. Am. J. Physiol. 1987, 253, C364-C368. [CrossRef]

60. Gaburjakova, J.; Gaburjakova, M. Comparison of the effects exerted by luminal $\mathrm{Ca}^{2+}$ on the sensitivity of the cardiac ryanodine receptor to caffeine and cytosolic $\mathrm{Ca}^{2+}$. J. Membr. Biol. 2006, 212, 17-28. [CrossRef]

61. Barry, P.H.; Lewis, T.M.; Moorhouse, A.J. An optimised $3 \mathrm{M} \mathrm{KCl}$ salt-bridge technique used to measure and validate theoretical liquid junction potential values in patch-clamping and electrophysiology. Eur. Biophys. J. 2013, 42, 631-646. [CrossRef] [PubMed]

62. Dawson, D.C. Permeability and conductance of ion channels a primer. In Molecular Biology of Membrane Transport Disorders; Schultz, S.G., Andreoli, T.E., Brown, A.M., Fambrough, D.M., Hoffman, J.F., Welsh, M.J., Eds.; Springer: Boston, MA, USA, 1996; pp. 87-110.

63. Goldman, D.E. Potential, impedance, and rectification in membranes. J. Gen. Physiol. 1943, 27, 37-60. [CrossRef] [PubMed]

64. Hodgkin, A.L.; Katz, B. The effect of sodium ions on the electrical activity of the giant axon of the squid. J. Physiol. 1949, 108, 37-77. [CrossRef] [PubMed]

65. Lindsay, A.R.; Manning, S.D.; Williams, A.J. Monovalent cation conductance in the ryanodine receptor-channel of sheep cardiac muscle sarcoplasmic reticulum. J. Physiol. 1991, 439, 463-480. [CrossRef] [PubMed]

66. Tinker, A.; Lindsay, A.R.G.; Williams, A.J. A model for ionic conduction in the ryanodine receptor channel of sheep cardiac muscle sarcoplasmic reticulum. J. Gen. Physiol. 1992, 100, 495-517. [CrossRef]

67. Stern, M.D. Buffering of calcium in the vicinity of a channel pore. Cell Calcium 1992, 13, 183-192. [CrossRef]

68. Buffle, J.; Zhang, Z.; Startchev, K. Metal flux and dynamic speciation at (bio)interfaces. Part I: Critical evaluation and compilation of physicochemical parameters for complexes with simple ligands and fulvic/humic substances. Environ. Sci. Technol. 2007, 41, 7609-7620. [CrossRef]

69. Tanaka, M.; Funahashi, S.; Shirai, K. Kinetics of the ligand substitution reaction of the zinc(II)-4-(2-pyridylazo)resorcinol complex with (ethylene glycol)bis(2-aminoethyl ether)- $N, N, N^{\prime}, N^{\prime}$-tetraacetic acid. Inorg. Chem. 1968, 7, 573-578. [CrossRef]

70. Takada, T.; Kiyama, M.; Torii, H.; Asai, T.; Takano, M.; Nakanishi, N. Effect of pH values on the formation and solubility of Zinc compounds. Bull. Inst. Chem. Res. Kyoto Univ. 1978, 56, 242-246.

71. Reichle, R.A.; Mccurdy, K.G.; Hepler, L.G. Zinc hydroxide: Solubility product and hydroxy-complex stability constants from $12.5^{\circ} \mathrm{C}-75^{\circ} \mathrm{C}$. Can. J. Chem. 1975, 53, 3841-3845. [CrossRef]

72. Brown, I.D. What factors determine cation coordination numbers? Acta Cryst. 1988, B44, 545-553. [CrossRef]

73. Smith, D.W. Ionic hydration enthalpies. J. Chem. Educ. 1977, 54, 540-542. [CrossRef]

74. Krezel, A.; Maret, W. The biological inorganic chemistry of zinc ions. Arch. Biochem. Biophys. 2016, 611, 3-19. [CrossRef]

75. $\mathrm{Xu}, \mathrm{L} . ;$ Mann, G.; Meissner, G. Regulation of cardiac $\mathrm{Ca}^{2+}$ release channel (ryanodine receptor) by $\mathrm{Ca}^{2+}, \mathrm{H}^{+}, \mathrm{Mg}^{2+}$, and adenine nucleotides under normal and simulated ischemic conditions. Circ. Res. 1996, 79, 1100-1109. [CrossRef]

76. Laver, D.R.; Eager, K.R.; Taoube, L.; Lamb, G.D. Effects of cytoplasmic and luminal pH on Ca ${ }^{2+}$ release channels from rabbit skeletal muscle. Biophys. J. 2000, 78, 1835-1851. [CrossRef]

77. Kettlun, C.; Gonzales, A.; Rios, E.; Fill, M. Unitary $\mathrm{Ca}^{2+}$ current through mammalian cardiac and amphibian skeletal muscle ryanodine receptor channel under near-physiological ionic conditions. J. Gen. Physiol. 2003, 122, 407-417. [CrossRef]

78. Mejía-Alvarez, R.; Kettlun, C.; Ríos, E.; Stern, M.; Fill, M. Unitary Ca ${ }^{2+}$ current through cardiac ryanodine receptor channels under quasi-physiological ionic conditions. J. Gen. Physiol. 1999, 113, 177-186. [CrossRef]

79. Gillespie, D.; Chen, H.Y.; Fill, M. Is ryanodine receptor a calcium or magnesium channel? Roles of $\mathrm{K}^{+}$and $\mathrm{Mg}^{2+}$ during Ca ${ }^{2+}$ release. Cell Calcium 2012, 51, 427-433. [CrossRef]

80. Krishna, S.S.; Majumdar, I.; Grishin, N.V. Structural classification of zinc fingers: Survey and summary. Nucleic Acids Res. 2003, 31, 532-550. [CrossRef]

81. Uchida, K.; Miyauchi, H.; Furuichi, T.; Michikawa, T.; Mikoshiba, K. Critical regions for activation gating of the inositol 1,4,5-trisphosphate receptor. J. Biol. Chem. 2003, 278, 16551-16560. [CrossRef]

82. Bhanumathy, C.; Da Fonseca, P.C.A.; Morris, E.P.; Joseph, S.K. Identification of functionally critical residues in the channel domain of inositol trisphosphate receptors. J. Biol. Chem. 2012, 287, 43674-43684. [CrossRef]

83. Serysheva, I.I. Toward a high-resolution structure of $\mathrm{IP}_{3} \mathrm{R}$ channel. Cell Calcium 2014, 56, 125-132. [CrossRef]

84. Wolfe, S.A.; Nekludova, L.; Pabo, C.O. DNA recognition by $\mathrm{Cys}_{2} \mathrm{His}_{2}$ zinc finger proteins. Annu. Rev. Biophys. Biomol. Struct. 2000, 29, 183-212. [CrossRef]

85. Larkin, M.A.; Blackshields, G.; Brown, N.P.; Chenna, R.; McGettingan, P.A.; McWilliam, H.; Valentin, F.; Wallace, I.M.; Wilm, A.; Lopez, R.; et al. Clustal W and Clustal X version 2.0. Bioinformatics 2007, 23, 2947-2948. [CrossRef]

86. Witkiewicz-Kucharczyk, A.; Bal, W. Damage of zinc fingers in DNA repair proteins, a novel molecular mechanism in carcinogenesis. Toxicol. Lett. 2006, 162, 29-42. [CrossRef]

87. Sénèque, O.; Bonnet, E.; Joumas, F.L.; Latour, J.M. Cooperative metal binding and helical folding in model peptides of treble-clef zinc fingers. Chem. Eur. J. 2009, 15, 4798-4810. [CrossRef]

88. Sénèque, O.; Latour, J.-M. Coordination properties of zinc finger peptides revisited: Ligand competition studies reveal higher affinities for zinc and cobalt. J. Am. Chem. Soc. 2010, 132, 17760-17774. [CrossRef] 
89. Woodier, J.; Rainbow, R.D.; Stewart, A.J.; Pitt, S.J. Intracellular zinc modulates cardiac ryanodine receptor-mediated calcium release. J. Biol. Chem. 2015, 290, 17599-17610. [CrossRef]

90. Reilly-O'Donnell, B.; Robertson, G.B.; Karumbi, A.; McIntyre, C.; Bal, W.; Nishi, M.; Takeshima, H.; Stewart, A.J.; Pitt, S.J Dysregulated $\mathrm{Zn}^{2+}$ homeostasis impairs cardiac type-2 ryanodine receptor and mitsugumin 23 functions, leading to sarcoplasmic reticulum $\mathrm{Ca}^{2+}$ leakage. J. Biol. Chem. 2017, 292, 13361-13373. [CrossRef]

91. Liu, Y.; Porta, M.; Qin, J.; Ramos, J.; Nani, A.; Shannon, T.R.; Fill, M. Flux regulation of cardiac ryanodine receptor channels. J. Gen. Physiol. 2010, 135, 15-27. [CrossRef]

92. Baddeley, D.; Jayasinghe, I.D.; Lam, L.; Rossberger, S.; Cannell, M.B.; Soeller, C. Optical single-channel resolution imaging of the ryanodine receptor distribution in rat cardiac myocytes. Proc. Natl. Acad. Sci. USA 2009, 106, 22275-22280. [CrossRef]

93. Hayashi, T.; Martone, M.E.; Yu, Z.; Thor, A.; Doi, M.; Holst, M.J.; Ellisman, M.H.; Hoshijima, M. Three-dimensional electron microscopy reveals new details of membrane systems for $\mathrm{Ca}^{2+}$ signaling in the heart. J. Cell Sci. 2009, 122, 1005-1013. [CrossRef]

94. Petering, D.H.; Huang, M.; Moteki, S.; Shaw, C.F., 3rd. Cadmium and lead interactions with transcription factor IIIA from Xenopus laevis: A model for zinc finger protein reactions with toxic metal ions and metallothionein. Mar. Environ. Res. 2000, 50, 89-92. [CrossRef]

95. Huang, M.; Krepkiy, D.; Hu, W.; Petering, D.H. Zn-, Cd-, and Pb-transcription factor IIIA: Properties, DNA binding, and comparison with TFIIIA-finger 3 metal complexes. J. Inorg. Biochem. 2004, 98, 775-785. [CrossRef]

96. Kothinti, R.; Blodgett, A.; Tabatabai, N.M.; Petering, D.H. Zinc finger transcription factor $\mathrm{Zn}_{3}-\mathrm{Sp} 1$ reactions with Cd ${ }^{2+}$. Chem. Res. Toxicol. 2010, 23, 405-412. [CrossRef]

97. Malgieri, G.; Zaccaro, L.; Leone, M.; Bucci, E.; Esposito, S.; Baglivo, I.; Del Gatto, A.; Russo, L.; Scandurra, R.; Pedone, P.V.; et al Zinc to cadmium replacement in the A. thaliana SUPERMAN Cys ${ }_{2} \mathrm{His}_{2}$ zinc finger induces structural rearrangements of typical DNA base determinant positions. Biopolymers 2011, 95, 801-810. [CrossRef]

98. Ebashi, S. Excitation-contraction coupling and the mechanism of muscle contraction. Ann. Rev. Physiol. 1991, 53, 1-17. [CrossRef]

99. Flockerzi, V.; Oeken, H.-J.; Hofmarm, F. Purification of a functional receptor for calcium-channel blockers from rabbit skeletalmuscle microsomes. Eur. J. Biochem. 1986, 161, 217-224. [CrossRef]

100. Pessah, I.N.; Zimanyi, I. Characterization of multiple [3H]ryanodine binding sites on the $\mathrm{Ca}^{2+}$ release channel of sarcoplasmic reticulum from skeletal and cardiac muscle: Evidence for a sequential mechanism in ryanodine action. Mol. Pharmacol. 1991, 39, 679-689.

101. Lai, F.A.; Misra, M.; Xu, L.; Smith, H.A.; Meissner, G. The ryanodine receptor-Ca ${ }^{2+}$ release channel complex of skeletal muscle sarcoplasmic reticulum. Evidence for a cooperatively coupled, negatively charged homotetramer. J. Biol. Chem. 1989, 264, 16776-16785. [CrossRef]

102. Fukuda, J.; Kawa, K. Permeation of manganese, cadmium, zinc, and beryllium through calcium channels of an insect muscle membrane. Science 1977, 196, 309-311. [CrossRef]

103. Kawa, K. Zinc-dependent action potentials in giant neurons of the snail, Euhadra quaestia. J. Membr. Biol. 1979, 49, 325-344. [CrossRef]

104. Atar, D.; Backx, P.H.; Appel, M.M.; Gao, W.D.; Marban, E. Excitation-transcription coupling mediated by zinc influx through voltage-dependent calcium channels. J. Biol. Chem. 1995, 270, 2473-2477. [CrossRef]

105. Kerchner, G.A.; Canzoniero, L.M.T.; Yu, S.P.; Ling, C.; Choi, D.W. $\mathrm{Zn}^{2+}$ current is mediated by voltage-gated Ca ${ }^{2+}$ channels and enhanced by extracellular acidity in mouse cortical neurones. J. Physiol. 2000, 528, 39-52. [CrossRef]

106. Gillespie, D.; Eisenberg, R.S. Physical descriptions of experimental selectivity measurements in ion channels. Eur. Biophys. J. 2002, 31, 454-466. [CrossRef]

107. Dubyak, G.R. Ion homeostasis, channels, and transporters: An update on cellular mechanisms. Adv. Physiol. Educ. 2004, 28, 143-154. [CrossRef]

108. Chen, W.; Steenberg, C.; Levy, L.A.; Vance, J.; London, R.E.; Murphy, E. Measurements of free Ca ${ }^{2+}$ on sarcoplasmic reticulum in perfuse rabbit heart loaded with 1,2-bis (2-amino-5,6-difluorophenoxy)ethane- $N, N, N^{\prime}, N^{\prime}$-tetraacetic acid by 19F NMR. J. Biol. Chem. 1996, 271, 7398-7403. [CrossRef]

109. Shannon, T.R.; Bers, D.M. Assessment of intra-SR free [Ca] and buffering in rat heart. Biophys. J. 1997, 73, 1524-1531. [CrossRef]

110. Chabosseau, P.; Tuncay, E.; Meur, G.; Bellomo, E.A.; Hessels, A.; Hughes, S.; Johnson, P.R.; Bugliani, M.; Marchetti, P.; Turan, B.; et al. Mitochondrial and ER-targeted eCALWY probes reveal high levels of free $\mathrm{Zn}^{2+}$. ACS Chem. Biol. 2014, 9, 2111-2120. [CrossRef]

111. Fuchs, F. Ion exchange properties of the calcium receptor site of troponin. Biochim. Biophys. Acta Bioenerg. 1971, 245, 221-229. [CrossRef]

112. Witte, K.K.; Clark, A.L.; Cleland, J.G. Chronic heart failure and micronutrients. J. Am. Coll. Cardiol. 2001, 37, 1765-1774. [CrossRef]

113. Shokrzadeh, M.; Ghaemian, A.; Salehifar, E.; Aliakbari, S.; Saravi, S.S.; Ebrahimi, P. Serum zinc and copper levels in ischemic cardiomyopathy. Biol. Trace Elem. Res. 2009, 127, 116-123. [CrossRef] [PubMed]

114. Wang, S.; Wang, B.; Wang, Y.; Tong, Q.; Liu, Q.; Sun, J.; Zheng, Y.; Cai, L. Zinc prevents the development of diabetic cardiomyopathy in $\mathrm{db} / \mathrm{db}$ mice. Int. J. Mol. Sci. 2017, 18, 580. [CrossRef] [PubMed]

115. Cohen, N.; Golik, A. Zinc balance and medications commonly used in the management of heart failure. Heart Fail. Rev. 2006, 11, 19-24. [CrossRef] 
116. Karagulova, G.; Yue, Y.; Moreyra, A.E.; Boutjdir, M.; Korichneva, I. Protective role of intracellular zinc in myocardial ischemia/reperfusion is associated with preservation of protein kinase C isoforms. J. Pharmacol. Exp. Ther. 2007, 321, 517-525. [CrossRef]

117. Frustaci, A.; Sabbioni, E.; Fortaner, S.; Massimo, F.; del Torchio, R.; Tafani, M.; Morgante, E.; Ciriolo, M.R.; Russo, M.A.; Chimenti, C. Selenium- and zincdeficient cardiomyopathy in human intestinal malabsorption: Preliminary results of selenium/zinc infusion. Eur. J. Heart Fail. 2012, 14, 202-210. [CrossRef]

118. Rosenblum, H.; Bikdeli, B.; Wessler, J.; Gupta, A.; Jacoby, D.L. Zinc deficiency as a reversible cause of heart failure. Tex. Heart Inst. J. 2020, 47, 152-154. [CrossRef]

119. Furuichi, T.; Yoshikawa, S.; Miyawaki, A.; Wada, K.; Maeda, N.; Mikoshiba, K. Primary structure and functional expression of the inositol 1,4,5-trisphosphate-binding protein P400. Nature 1989, 342, 32-38. [CrossRef] 